Prepared in cooperation with the U.S. Fish and Wildlife Service

Range-Wide Network of Priority Areas for Greater Sage-Grouse-A Design for Conserving Connected Distributions or Isolating Individual Zoos?

Open-File Report 2015-1158 



\section{Range-Wide Network of Priority Areas for Greater Sage-Grouse-A Design for Conserving Connected Distributions or Isolating Individual Zoos?}

By Michele R. Crist, Steven T. Knick, and Steven E. Hanser

Prepared in cooperation with the U.S. Fish and Wildlife Service

Open-File Report 2015-1158 


\section{U.S. Department of the Interior SALLY JEWELL, Secretary}

\section{U.S. Geological Survey \\ Suzette M. Kimball, Acting Director}

U.S. Geological Survey, Reston, Virginia: 2015

For more information on the USGS-the Federal source for science about the Earth, its natural and living resources, natural hazards, and the environment-visit http://www.usgs.gov/ or call 1-888-ASK-USGS (1-888-275-8747).

For an overview of USGS information products, including maps, imagery, and publications, visit http://www.usgs.gov/pubprod/.

Any use of trade, firm, or product names is for descriptive purposes only and does not imply endorsement by the U.S. Government.

Although this information product, for the most part, is in the public domain, it also may contain copyrighted materials as noted in the text. Permission to reproduce copyrighted items must be secured from the copyright owner.

Suggested citation:

Crist, M.R., Knick, S.T., and Hanser, S.E., 2015, Range-wide network of priority areas for greater sagegrouse-A design for conserving connected distributions or isolating individual zoos?:

U.S. Geological Survey Open-File Report 2015-1158, 34 p., http://dx.doi.org/10.3133/ofr20151158.

ISSN 2331-1258 (online) 


\section{Contents}

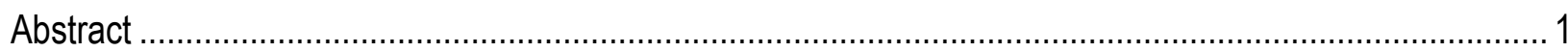

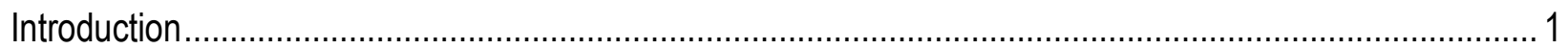

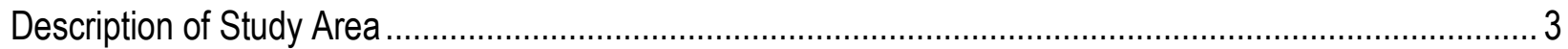

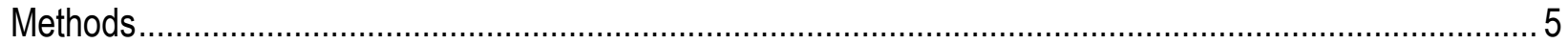

Priority Areas as a Spatial Network ............................................................................................ 5

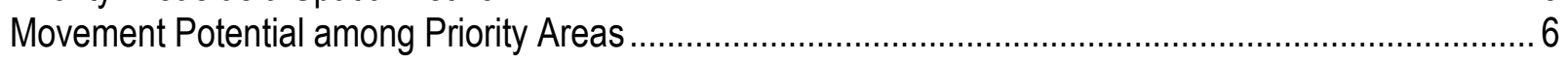

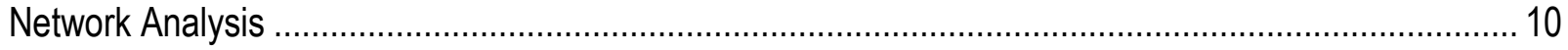

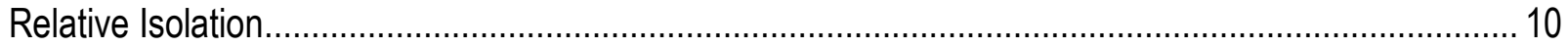

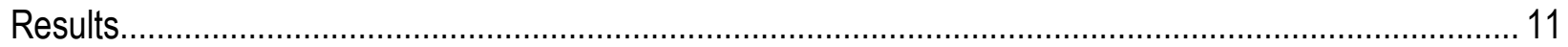

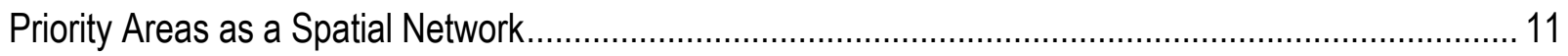

Connectivity among Priority Areas ……………………………................................................ 14

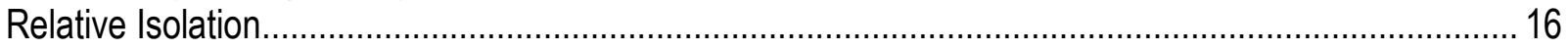

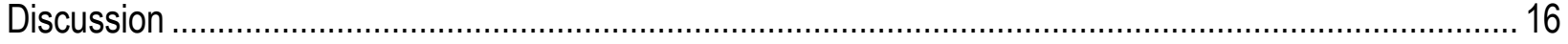

Priority Areas as a Spatial Network ........................................................................................... 16

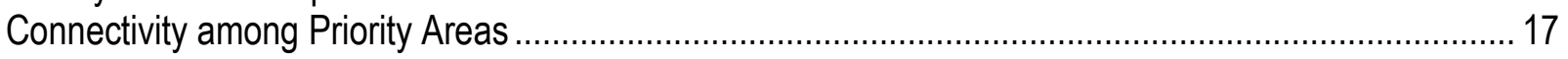

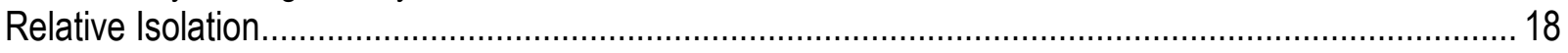

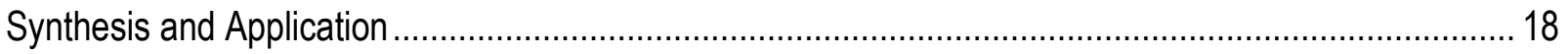

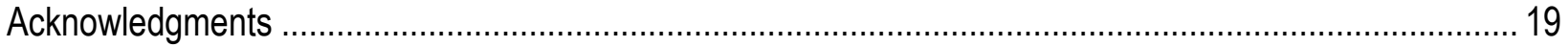

References Cited ................................................................................................................ 20

Appendix A. Crosswalk Table Depicting Priority Area Identifiers, U.S. Fish and Wildlife Service Unique Identifiers, Sage-Grouse Population Name, and Management Zone...................................................... 24

Appendix B. Centrality Results for Degree and Betweenness Metrics for Each Priority Area...................... 30

\section{Figures}

Figure 1. Study area and designated priority areas across the sage-grouse range in western North America represented as a network of nodes and links.............................................................. 4

Figure 2. Habitat similarity index (HSI) values for greater sage-grouse across their historical range. .......... 9 Figure 3. Priority area importance and connectivity for betweenness centrality and ranked across the network.

Figure 4. Relative contribution of each priority area to range-wide cumulative percent betweenness

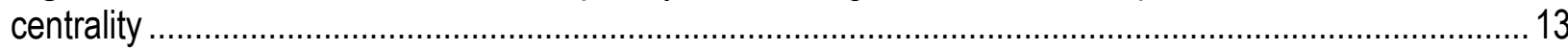

Figure 5. Cumulative distribution of each priority area's contribution to total betweenness centrality ......... 14 Figure 6. Relative isolation of priority areas based on estimated potential for sage-grouse movement (Circuitscape; McRae and Shah, 2008)

\section{Tables}

Table 1. Partitions $(k)$ in a Mahalanobis $D^{2}$ model describing ecological minimums for the range-wide distribution of greater sage-grouse

Table 2. Summary statistics calculated for degree and betweenness centrality, and effective resistance and maximum current densities from Circuitscape (McRae and others, 2008)... 


\section{Conversion Factors}

International System of Units to Inch/Pound

\begin{tabular}{lcl}
\hline \multicolumn{1}{c}{ Multiply } & \multicolumn{1}{c}{ By obtain } \\
\hline Length & \\
\hline kilometer $(\mathrm{km})$ & 0.6214 & mile $(\mathrm{mi})$ \\
\hline Area & \\
\hline hectare (ha) & 2.471 & acre \\
square hectometer $\left(\mathrm{hm}^{2}\right)$ & 2.471 & acre \\
square kilometer $\left(\mathrm{km}^{2}\right)$ & 247.1 & acre \\
square kilometer $\left(\mathrm{km}^{2}\right)$ & 0.3861 & square mile $\left(\mathrm{mi}^{2}\right)$ \\
\hline
\end{tabular}

Vertical coordinate information is referenced to the North American Vertical Datum of 1988 (NAVD 88).

Horizontal coordinate information is referenced to the North American Datum of 1983 (NAD 83).

Elevation, as used in this report, refers to distance above the vertical datum. 


\title{
Range-Wide Network of Priority Areas for Greater Sage-Grouse-A Design for Conserving Connected Distributions or Isolating Individual Zoos?
}

\author{
By Michele R. Crist, Steven T. Knick, and Steven E. Hanser
}

\begin{abstract}
The network of areas delineated in 11 Western States for prioritizing management of greater sage-grouse (Centrocercus urophasianus) represents a grand experiment in conservation biology and reserve design. We used centrality metrics from social network theory to gain insights into how this priority area network might function. The network was highly centralized. Twenty of 188 priority areas accounted for 80 percent of the total centrality scores. These priority areas, characterized by large size and a central location in the range-wide distribution, are strongholds for greater sage-grouse populations and also might function as sources. Midranking priority areas may serve as stepping stones because of their location between large central and smaller peripheral priority areas. The current network design and conservation strategy has risks. The contribution of almost one-half $(n=93)$ of the priority areas combined for less than 1 percent of the cumulative centrality scores for the network. These priority areas individually are likely too small to support viable sage-grouse populations within their boundary. Without habitat corridors to connect small priority areas either to larger priority areas or as a clustered group within the network, their isolation could lead to loss of sage-grouse within these regions of the network.
\end{abstract}

\section{Introduction}

Greater sage-grouse (Centrocercus urophasianus; hereinafter, sage-grouse) is an endemic Galliform to arid and semiarid sagebrush (Artemisia spp.) landscapes of Western North America (Schroeder and others, 1999). Sage-grouse currently occupy approximately one-half of their presettlement habitat distribution and have recently received much attention for their long-term population declines (Schroeder and others, 2004; Garton and others, 2011). The U.S. Fish and Wildlife Service listed sage-grouse as a candidate species under the Endangered Species Act in 2010 concluding that protection was warranted although immediate conservation actions were precluded due to other higher priority species (U.S. Fish and Wildlife Service, 2010). Broadscale habitat loss and fragmentation from synergistic cycles of wildfire and conversion to invasive plant communities as well as from human land use is the primary cause of population declines (Knick and Connelly, 2011). The most pressing challenge to long-term sage-grouse persistence is conservation of remaining large and intact sagebrush landscapes (Stiver and others, 2006). 
The U.S. Fish and Wildlife Service, faced with legal challenges for delaying full protection under the Endangered Species Act, is currently reviewing the bird's status and is scheduled to issue an updated listing decision in September 2015. In an effort to avoid listing, the 11 Western States and Federal management agencies within the sage-grouse range have developed conservation plans embracing the concept of core or priority areas (Priority Areas for Conservation, PACs [U.S. Fish and Wildlife Service, 2013], or equivalent terms designated in individual State agency plans) - allowable spatial area of disturbance due to human land use, such as energy development, is tightly regulated and conservation actions are focused in areas with the highest number of sage-grouse and potentially the greatest benefit to the species. Land use is allowed to continue outside of priority areas under normal regulations.

The delineation of an entire species range spanning more than 2 million $\mathrm{km}^{2}$ (excluding the Canadian portion) into a binary division of priority and nonpriority areas may represent one of the largest experiments in conservation reserve design for a single species. Individual priority areas range in size from less than 1 to more than $83,000 \mathrm{~km}^{2}$ and encompass the broad spectrum of reserve design paradigms from single large to several small reserves. Although we do not know the minimum area required, the largest priority areas likely can support viable sage-grouse populations completely within their boundaries. However, the smallest priority areas clearly enclose much less than the annual range of a sage-grouse $\left(4-615 \mathrm{~km}^{2}\right.$; Connelly and others, 2011). Much scientific literature addressing conservation reserve design has stressed the importance of the inclusion and protection of habitat connectivity between conservation reserves to ensure individual movements, opportunity to shift habitats when needed, and facilitate genetic exchange (Crooks and Sanjayan, 2006). Therefore, numerous connected priority areas also may be necessary to provide seasonal habitats that can be separated by up to $160 \mathrm{~km}$ (Connelly and others, 2011; Smith, 2013). The two primary factors that influence populations, area and isolation (MacArthur and Wilson, 1967; Hanski and Gilpin, 1991; Hanski, 1999), are important metrics in understanding the efficacy of this conservation approach.

We used social network theory and centrality metrics (Moreno, 1932, 1934; Freeman, $1979,2004)$ to quantify and understand the potential for the delineated priority areas to function as a connected network to conserve sage-grouse populations. Our objectives were to:

1. Identify high-ranking priority areas within the network based on their location and number of connections to other priority areas,

2. Estimate the ability of other lower ranking priority areas within the network to function as stepping stones for maintaining connectivity among clusters of priority areas, and

3. Model relative isolation among priority areas based on movement potential in their surrounding environment. 


\section{Description of Study Area}

We included 2,030,230 $\mathrm{km}^{2}$ of the Western United States in our analysis of designated priority areas across the current sage-grouse range (Schroeder and others, 2004). The sagegrouse range is divided into seven management zones based on similar floristic and environmental characteristics (Stiver and others, 2006). The area contains a diversity of shrubland types of which landscapes dominated by sagebrush are the most important to sagegrouse. Mountain ranges, forest communities, and agricultural regions, particularly in broad plains of large river systems, are not used by sage-grouse and can act as barriers to their movements (Fedy and others, 2014). Lands used by sage-grouse are of mixed ownership (Knick, 2011). Public lands are dominant in the Western States and are managed primarily by the Bureau of Land Management and U.S. Forest Service for multiple uses. Private lands, characteristically those fertile lands with deep soils and access to water, constitute the greatest proportion of ownership in the northern and eastern parts of the sage-grouse range and can comprise more than two-thirds of the landscape used by sage-grouse (Doherty and others, 2010; Knick, 2011).

Each State used different criteria for delineating boundaries of priority areas but each generally incorporated metrics for sage-grouse populations (lek locations and breeding bird densities [Doherty and others, 2010]) and habitat areas (identified from known sage-grouse distributions or seasonal habitats for breeding, nesting, brood-rearing, or wintering areas derived from observations or telemetry data). In some cases, States also adjusted boundaries to exclude private lands, Federal lands approved for or in the process of being developed for energy and other management activities, and pre-existing development. The current range-wide management strategy, if not the ecological reality, is that each priority area bounds a homogeneous patch and that all priority areas are of equal importance.

We created a range-wide map of priority areas by combining the spatial boundaries of priority areas as delineated by the 11 States in Western North America (fig. 1, appendix A). Boundaries of polygons were merged between States when shared but followed State lines when adjoining priority areas did not match across borders. We also merged or removed priority areas less than $1 \mathrm{~km}^{2}$ that typically were slivers left after the State's original delineations and subsequent edits. The final map contained 188 priority areas ranging in size from approximately 1.1 to $83,000 \mathrm{~km}^{2}$ (appendix B). Mean size was approximately $16,600 \mathrm{~km}^{2}$. The frequency distribution consisted predominantly of smaller priority areas; 50 percent of the priority areas were less than $125 \mathrm{~km}^{2}$ and 90 percent were less than $3,300 \mathrm{~km}^{2}$. Total area included within priority areas was approximately $310,000 \mathrm{~km}^{2}$ and included 15 percent of our study area. 


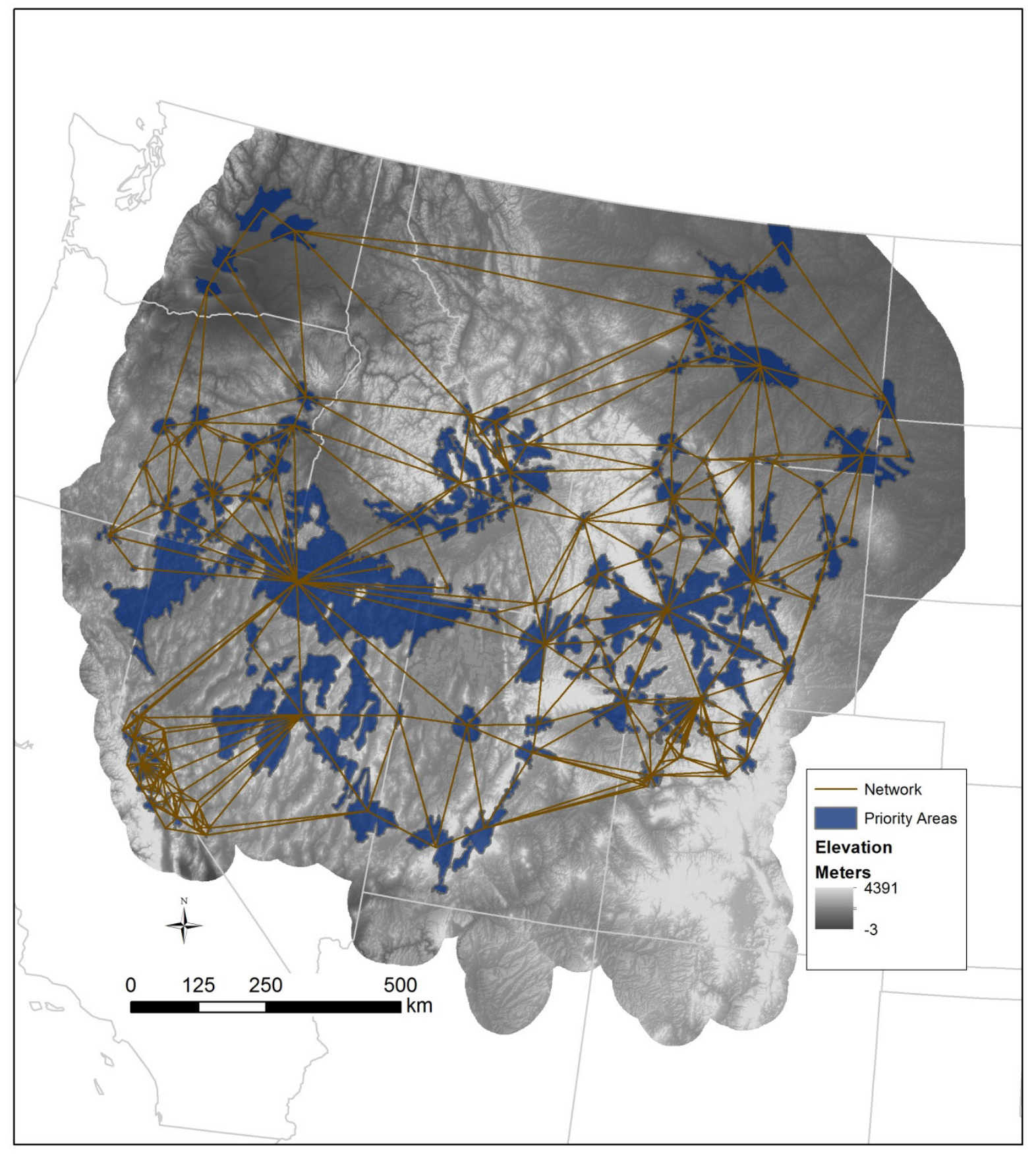

Figure 1. Study area and designated priority areas across the sage-grouse range in Western North America represented as a network of nodes and links. Background map is from U.S. Geological Survey National Elevation Data (NED; 2011; http://seamless.usgs.gov). 


\section{Methods}

\section{Priority Areas as a Spatial Network}

We described the spatial network of priority areas as a graph structured by nodes and connecting links (Diestel, 2005). To identify adjacencies, we delineated individual polygons around each priority area by creating Thiessen polygons where boundaries encompassed grid cells closest to each priority area relative to all other priority areas. Shared boundaries between Thiessen polygons identified neighboring priority areas. We then added links between each priority area and its neighbor's centroid. Thus, the network of conservation reserves currently designed for the sage-grouse range was represented by nodes and links across all priority areas (fig. 1).

We used analyses derived from social network theory (Wasserman and Faust, 2004) to identify priority areas that were highly important for connectivity within the range-wide network. Social network theory combines graph theory and centrality indices to characterize network structures by mapping and measuring relationships and flows (links) between people, groups, organizations, computers, and other entities (nodes) (Freeman, 2004; Wasserman and Faust, 2004; Diestel, 2005; Newman, 2010). Quantifying network centrality provides insight into the overall structure, connection, and function of a network, and is considered to be the fundamental characteristic describing a node's position in a network. Relative importance in social networks is measured by centrality metrics that emphasize number of connections to indicate relative position within the network. Networks can range from highly centralized, dominated by a few highly connected nodes, to more widely dispersed configurations in which connections are equally shared among all nodes.

We used two centrality metrics, degree and betweenness, to assess the relative importance of individual priority areas based on their position and number of connections within the overall range-wide network (Freeman, 1977, 2004; Wasserman and Faust, 2004; Newman, 2010). Relative importance estimated by degree centrality is based simply on number of connections to other nodes in the network; more connections indicate greater influence and a more central position in the network (Erdos and Gallai, 1960; Diestel, 2005). However, a priority area also might be important because its relative position connects clusters or groups of priority areas located in close proximity. Betweenness centrality quantifies the number of times a node acts as a bridge along the shortest path between two other nodes, thus indicating its importance in maintaining the network (Freeman, 1977; Freeman and others, 1991; Estrada, 2007; Brandes, 2008; González-Pereira and others, 2010). Nodes with high scores of betweenness centrality represent the primary foundation of the network's structure because a disproportionately high number of the shortest pathways go through them. These nodes funnel movement not only from adjacent nodes but also from nodes that could be located far away in the landscape (Bodin and Norberg, 2007). 


\section{Movement Potential among Priority Areas}

Connections in ecological networks are not without dimensions (as in social networks) but rather have a distance and environmental cost to move between nodes (Bunn and others, 2000; McRae and others, 2008; Carroll and others, 2012; LaPointe and others, 2013). To assess the relative importance of priority areas, we needed to combine number of connections with the ability to traverse the interstitial landscape matrix.

We calibrated movement potential by sage-grouse through the landscape by mapping a model of ecological minimum requirements (Knick and others, 2013). Sage-grouse may perceive a landscape quite differently when moving within a range, moving between seasonal ranges, or when dispersing. Similarly, connectivity for individual movements obtained from telemetry data might be different than connectivity derived from genetic information. For our study, we made the basic assumption that movement would be more likely in suitable environments that could be modeled across the entire range.

An ecological minimum, in concept, represents a multivariate construct of the basic requirements for a species. The model was developed from 23 variables describing land cover, fire history (area burned from 1980 to 2013), terrain (topographic accessibility [Sappington and others, 2007]), climate, edaphic, and anthropogenic features measured at our minimum mapping unit of $1-\mathrm{km}^{2}$ resolution across the sage-grouse range. Land-cover variables consisted of combined Landfire Existing Vegetation Type (http://www.landfire.gov/; Rollins, 2009) for big sagebrush, low sagebrush, salt desert shrub, exotic grassland, native grassland, pinyon-juniper woodland, conifer forest, and riparian associations. Climate variables were obtained from the PRISM Climate Group (Daly and others, 2004; Oregon State University, 2011) measured from 1998 to 2010 and included mean annual maximum and minimum temperatures, and mean annual precipitation. We described soils using available water capacity, salinity, and depth to rock (U.S. Department of Agriculture, 2011). Anthropogenic features included agriculture and development land cover (http://www.landfire.gov/), transmission lines, tall structures (communication towers, wind towers), roads, pipelines, and oil and gas wells. We produced a smoothed, continuous surface for most variables by averaging individual cell values within a 5-km radius moving window. We used mapped values for soils, which were in vector format, measured at the center of each $1-\mathrm{km}$ grid cell in the map.

We derived estimates of the ecological minimums using a partitioned Mahalanobis $\mathrm{D}^{2}$ model of presence only data (Dunn and Duncan, 2000; Rotenberry and others, 2002). Lek (breeding area) locations were used to indicate presence for a previous model of sage-grouse ecological minimums across their western range (Knick and others, 2013). However, we did not have permission to use lek data from all States across the sage-grouse range. Therefore, we assumed that the priority areas delineated by States captured higher quality habitat than occurred outside, despite having some areas excluded because of ownership or forecasted disturbance, and a large proportion of the sage-grouse population. We randomly selected 1,669 points within individual priority areas as presence data and extracted values for corresponding variables to calibrate models. Total number of presence points was obtained by proportional area expansion to the eastern part of the sage-grouse range after an initial 1,000 point random sample in a preliminary comparison of results from priority areas compared to the lek-based map in our previous study of the western range (Knick and others, 2013). We then performed a principal components analysis on 1,000 iterative samples created by bootstrapping the calibration data. The final model was created by subsequently averaging the PCA output after correcting for sign ambiguity (Bro and others, 2008) across all iterations. 
We evaluated model performance from the area under the curve (AUC) for a receiver operating characteristic (ROC) to assess sensitivity (fraction of habitat points correctly classified) and specificity (fraction of non-habitat points predicted as habitat) (Fielding and Bell, 1997). To generate presence data, we overlaid the 100 percent sage-grouse breeding densities (Doherty and others, 2010) representing spatial locations of all known sage-grouse breeding sites with our map of ecological minimums and selected all values that fell within the density boundaries. For absence data, we selected all values that fell outside of the breeding density boundaries. To calculate the AUC, we randomly sampled 5,000 presence points and 20,000 absence points. We also created a null presence/absence dataset by randomly sampling 20,000 points 1,000 times from the ecological minimums map. For each iteration, we divided the resulting sample into two datasets (null presence and null absence) based on a relatively equal proportion of the total rows and columns. We then sampled 10,000 points from each of the two datasets and computed a mean AUC score and distribution from all null samples. Means and distributions for model and null AUC scores then were used in a t-test for significance.

Principal component partition 14 met our criteria of having an eigenvalue $\leq 1$, a relative difference in eigenvalues among adjacent partitions (table 1), performance against evaluation data $(\mathrm{AUC}=0.80$; null $\mathrm{AUC}=0.50 ; 95 \% \mathrm{CI}=0.49$ and 0.50 ; t-test between the null AUC and true $\mathrm{AUC}=-3,775.0 ; \mathrm{p}<<0.001)$, and our subjective assessment of mapped results from different model partitions. We rescaled the mapped output to range continuously from 0 to 1 based on a $\chi^{2}$ distribution of the $\mathrm{D}^{2}$ distance; a value of 1 indicated environmental conditions identical to the mean vector of ecological minimum requirements, whereas a value near 0 indicated very dissimilar conditions (fig. 2).

We used circuit theory (McRae and others, 2008) to model movement pathways between all priority areas across our network. We assumed that sage-grouse moved more readily through areas meeting their ecological minimum requirements and used a scaled inverse of our mapped scores as a resistance surface (McRae and others, 2008; Spear and others, 2010; Beier and others, 2011; Zeller and others, 2012). Our resistance surface was calculated by multiplying habitat values by 100 and using the following function: ((habitat value - maximum habitat value) * -1$)+$ minimum habitat value). Resistance values ranged from 1, representing the lowest resistance/highest habitat value, to 100 (high resistance/lowest habitat value). We ran Circuitscape (Circuitscape version 4.0, http://www.circuitscape.org; McRae and Shah, 2008) using the pairwise mode to calculate connectivity between all pairs of priority areas. We treated priority areas as focal patches instead of individual nodes in the modeling process: evaluating habitat pathways from priority area polygon boundaries rather than nodes captured the influence of priority area structure and size in influencing current flow. Effective resistance distances, the relative distance that incorporates the resistance to a species movements across a heterogeneous landscape and used as an estimate of connectivity, were calculated iteratively between all priority area pairs and maps of current densities. We calculated electric current flowing through the resistance landscape between each pair to produce cumulative and maximum current densities across all pair-wise combinations. Our approach thus incorporated multiple dispersal pathways and landscape heterogeneity. 
Table 1. Partitions $(k)$ in a Mahalanobis $D^{2}$ model describing ecological minimums for the range-wide distribution of greater sage-grouse.

\begin{tabular}{cc}
\hline Partition $(\boldsymbol{k})$ & Eigenvalue \\
\hline 1 & 3.18 \\
2 & 2.89 \\
3 & 1.87 \\
4 & 1.76 \\
5 & 1.68 \\
6 & 1.42 \\
7 & 1.31 \\
8 & 0.99 \\
9 & 0.96 \\
10 & 0.93 \\
11 & 0.85 \\
12 & 0.80 \\
13 & 0.76 \\
14 & 0.63 \\
15 & 0.59 \\
16 & 0.49 \\
17 & 0.44 \\
18 & 0.40 \\
19 & 0.34 \\
20 & 0.32 \\
21 & 0.24 \\
22 & 0.14 \\
23 & 0.04 \\
\hline
\end{tabular}




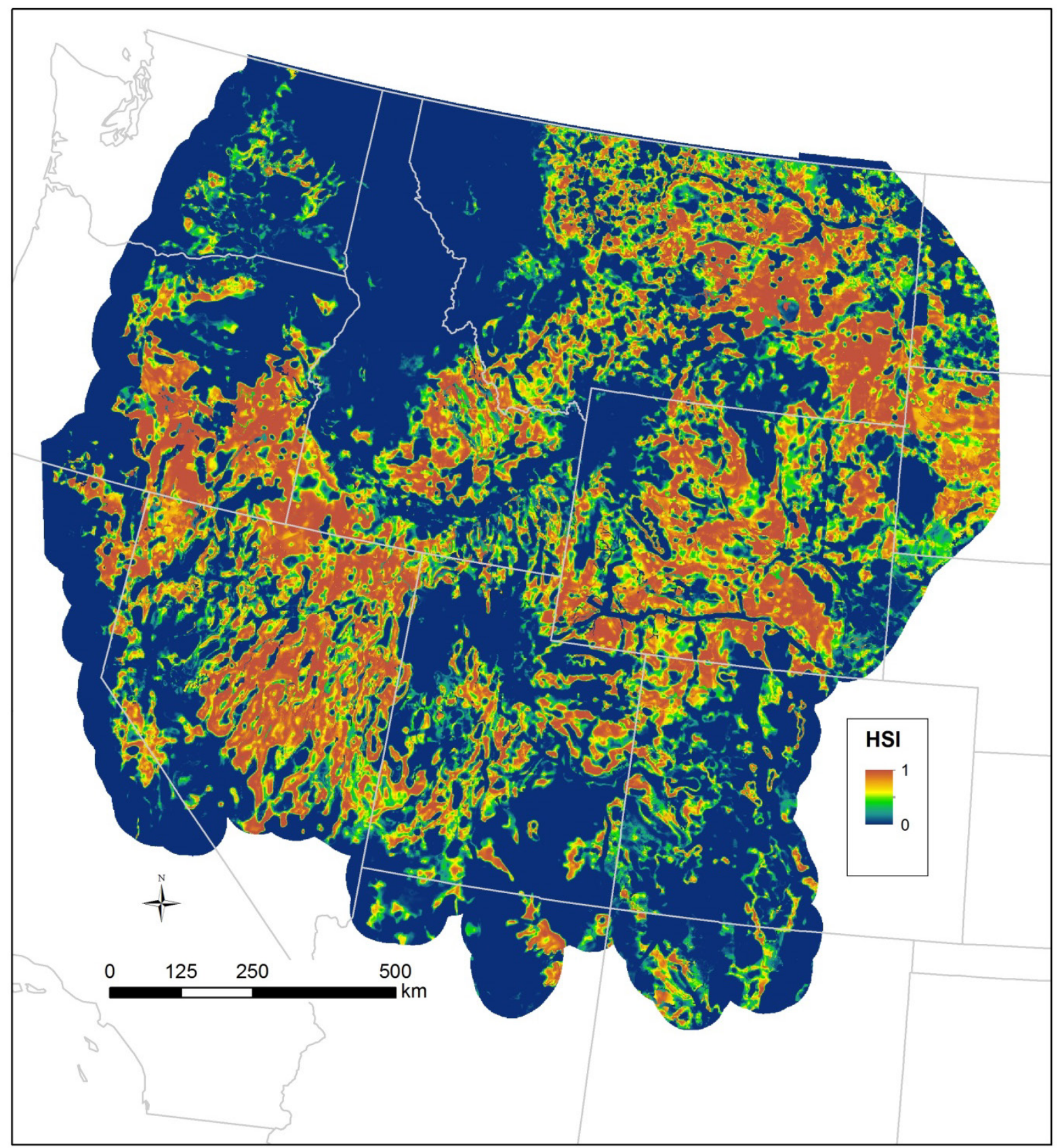

Figure 2. Habitat similarity index (HSI) values for greater sage-grouse across their historical range. HSI values represent the relationship of environmental values at map locations to the multivariate mean vector of minimum requirements for sage-grouse defined by land cover, anthropogenic variables, soil, topography, and climate. 


\section{Network Analysis}

We applied the effective resistance distances calculated between priority areas to our priority area network. We exported the attribute table of our line network shapefile and built a matrix based on priority area IDs, where "0" was assigned to indicate non-adjacency for a priority area pair (where the two priority areas are not linked in the network), and a "1" indicates adjacency (priority area pairs are linked). We assigned the resulting pair-wise effective resistance distances as a cost between adjacent priority areas in the matrix to all priority pair adjacencies labeled with a " 1 ". For example, a low effective resistance distance represents a relative capability for sage-grouse movements between the priority area pair based on similarity to habitats within priority areas. We rebuilt our node and link network from our matrices using the igraph package in R (Csardi and Nepusz, 2006; R Core Team, 2013) to calculate centrality. Links connecting adjacent priority areas represent a relation between the priority areas based on the effective resistance distance. The final graph represented the priority area network's spatial structure of connectivity.

We calculated our centrality metrics, degree and betweenness, using the igraph package and computed summary statistics of our centrality results using R (Csardi and Nepusz, 2006; R Core Team, 2013). We also computed a cumulative distribution curve for resulting betweenness centrality values and used the incremental contribution by each priority areas to assess its contribution to overall network centrality. We used the distribution to rank and identify central priority areas that contribute the most in maintaining a connected network and to identify priority areas that function as stepping stones in promoting connectivity to the central priority areas.

\section{Relative Isolation}

Our final objective was to model the relative isolation of priority areas across the historical range of sage-grouse. Results from Circuitscape were used to map habitat linkages among all priority areas and identify clusters of connected priority areas within our network. Circuit theory is advantageous for quantifying connectivity in this manner because of its ability to simultaneously evaluate the combined contributions of multiple pathways to dispersal in heterogeneous landscapes, and identify areas important for connectivity conservation (McRae, 2006; McRae and others, 2008). We used visual observations of the maximum current densities and computed effective resistance distances resulting from Circuitscape to identify areas where habitat connectivity is high or low between priority areas. We chose to evaluate the maximum current density map because maximum values help to remove the confounding effects of network configuration (halo effect) in the Circuitscape results. Again, greater connectivity among priority areas was reflected by a larger number of connected pathways and lower effective resistance distance values (McRae and Shah, 2008; McRae and others, 2008). We also visually identified locations of high current densities that may function as bottlenecks (pinch points) to sage-grouse movements where alternative pathways are not available (McRae and others, 2008). These locations may represent conservation priorities for sage-grouse because their loss may disrupt connectivity among the priority area network. 


\section{Results}

\section{Priority Areas as a Spatial Network}

Average number of connections from each priority area to adjacent neighbors averaged 11 and ranged from 2 to 50 (fig. 3). Betweenness centrality scores ranged from 0 to 11,414 (table 2; appendix B); the average betweenness centrality was 475 (table 2), indicating that most priority areas were contributing little to the range-wide centrality. The largest priority area (Priority Area ID 48), which combined individual State polygons in northeastern Oregon, western California, northern Nevada, southern Idaho, and western Utah, exhibited the highest number of adjacent neighbors $(n=50)$ and highest betweenness centrality value, signifying its importance in connecting the network.

Twenty priority areas explained 80 percent of the total betweenness centrality value and were likely the central priority areas for maintaining a connected reserve network (fig. 4). Two priority areas that exhibited the highest betweenness centrality scores and explained 20 percent of total centrality were the largest single polygon (Priority Area ID 48) and a priority area centrally located in Wyoming (Priority Area ID 110). Priority areas that were within the 80-99 percent cumulative distribution scored lower in centrality compared to the central priority areas but may still contribute largely by functioning as stepping stones maintaining connections across the most central 20 priority areas. These priority areas typically were located between the highest- and lowest-scoring priority areas, mid-sized in area, and were distributed across the entire range rather than having a more central location.

Ninety-three priority areas that scored a 0 for betweenness centrality were characterized by small size (averaging approximately $350 \mathrm{~km}^{2}$ ), and were either isolated between large priority areas where the shape of the surrounding large priority areas limited the number of connections, or were located on the periphery of the range. Although these small priority areas were not central in maintaining the overall network, most scored low in the effective resistance distance results (figs. 4 and 5; appendix B) indicating high connectivity to their neighboring priority areas.

Table 2. Summary statistics calculated for degree and betweenness centrality, and effective resistance and maximum current densities from Circuitscape (McRae and others, 2008).

\begin{tabular}{lccc}
\hline \multicolumn{1}{c}{ Priority Areas } & Mean & Minimum & Maximum \\
\hline Distance between Priority Areas (km) & 99.3 & 2.7 & 843.3 \\
Degree Centrality Metric & 10.6 & 2.0 & 50.0 \\
Betweenness Centrality Metric & 475 & 0 & 11,414 \\
Priority Area Effective Resistance & 4.4 & $<0.1$ & 35.8 \\
Maximum Current Densities & 0.1 & 0.0 & 1.0 \\
\hline
\end{tabular}




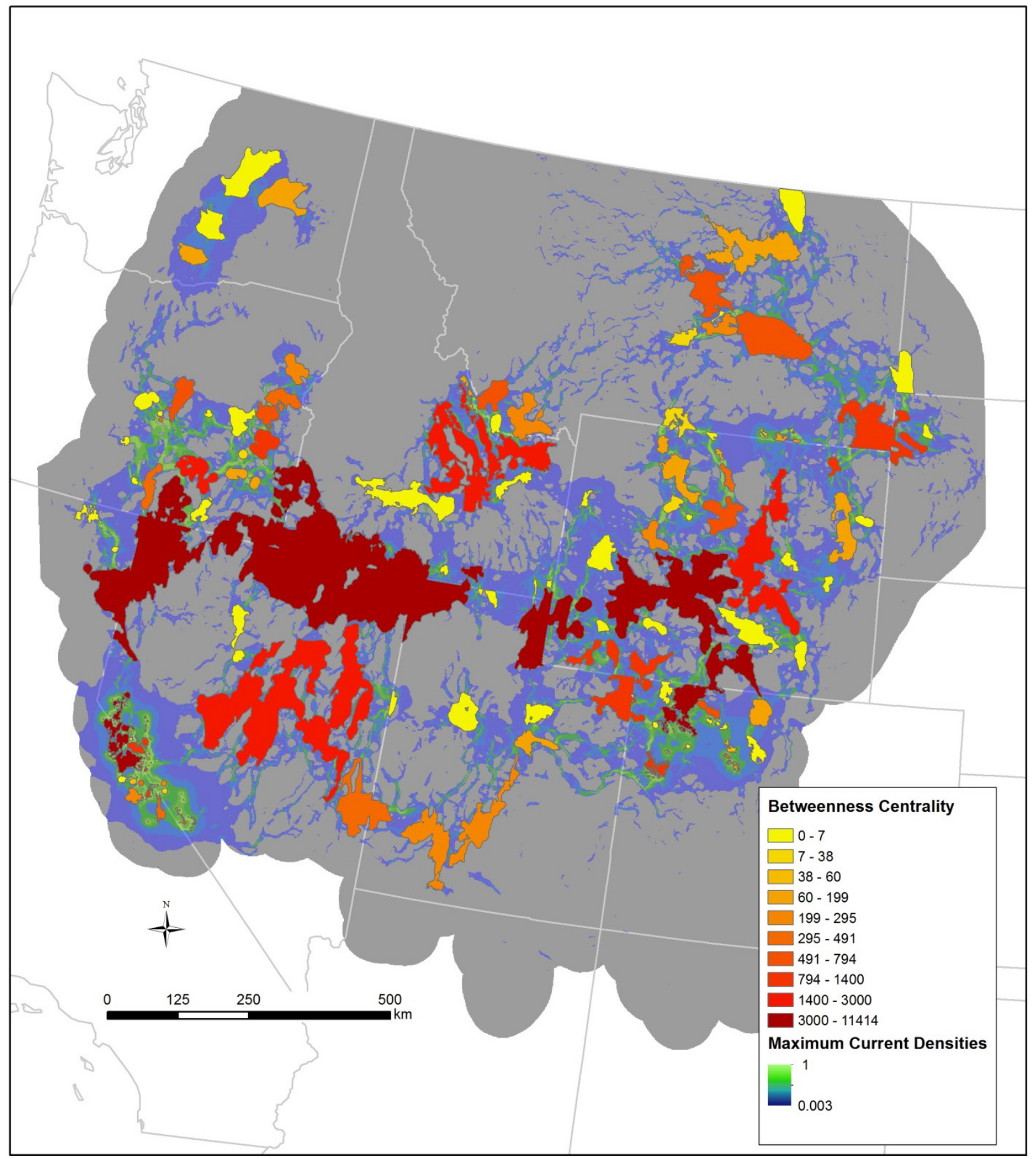

Figure 3. Priority area importance and connectivity for betweenness centrality and ranked across the network. Potential for sage-grouse movements was estimated between priority areas and used to determine each priority area's centrality based on the number of movement pathways available between priority areas. Current densities were displayed using a histogram equalize stretch. 


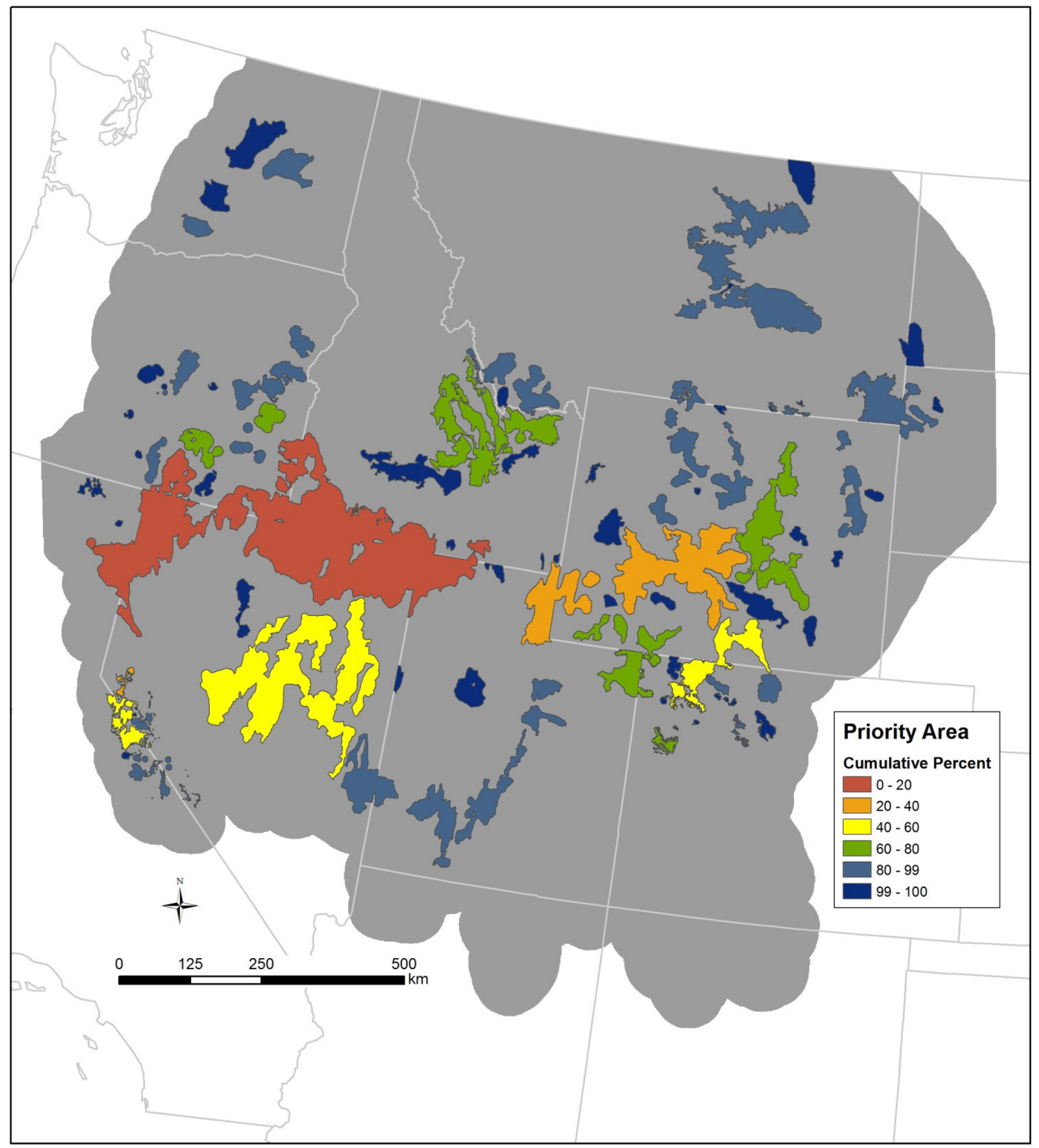

Figure 4. Relative contribution of each priority area to range-wide cumulative percent betweenness centrality. Priority area colors in map correspond with figure 5 . 


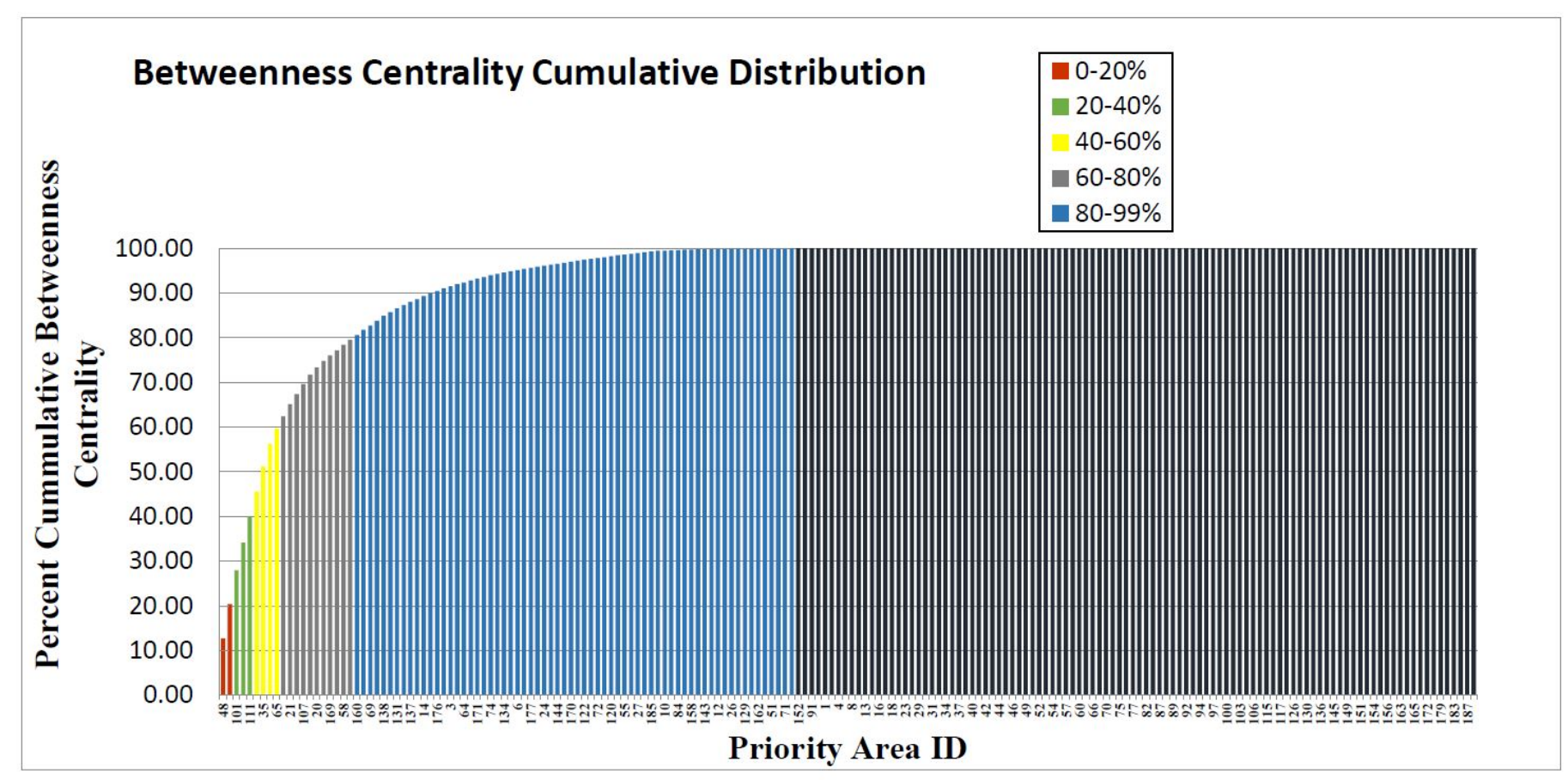

Figure 5. Cumulative distribution of each priority area's contribution to total betweenness centrality. Graph colors correspond to mapped priority areas in figure 4.

\section{Connectivity among Priority Areas}

Movement potential, estimated by Circuitscape current densities (fig. 6), coupled with the relatively low mean for priority area effective resistance distance (mean $=4.4$; table 2 ) indicated a high degree of connectivity across the network characterized by numerous and multiple pathways between most of the priority areas. The map reflecting maximum current densities highlighted areas of high current flow between priority areas that may be important habitat linkages (pinch points). Their loss may result in disconnections across the entire network or result in the use of less efficient (more costly) habitat pathways connecting priority areas (fig. 6). A number of linkages have portions of high current densities that depict pinch points where connectivity is high but constrained due to either natural or anthropogenic barriers to sage-grouse movements surrounding the pinch points. Our map of maximum current densities also highlighted priority area clusters where current flow was high between priority areas and low surrounding a group of priority areas. 


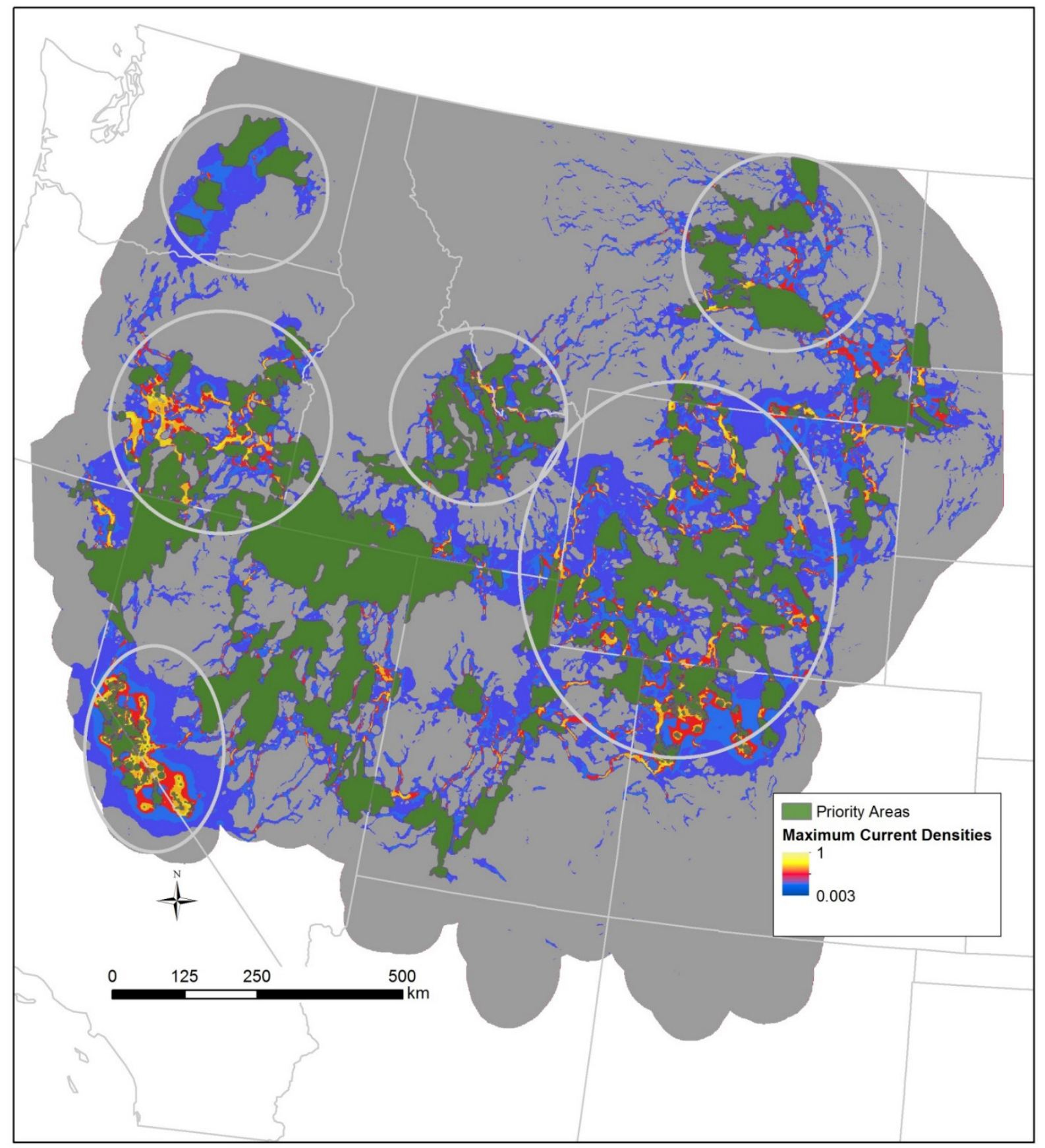

Figure 6. Relative isolation of priority areas based on estimated potential for sage-grouse movement (Circuitscape; McRae and Shah, 2008). Inverted HSI values were used as a measure of landscape resistance. Six clusters of priority areas are circled where connectivity between priority areas was high in comparison to surrounding environment. High to medium current densities represent pinch points. 


\section{Relative Isolation}

Low current densities highlighted areas where habitat quality was more fragmented or where barriers for sage-grouse movements may exist. Mean maximum current density across the study area was low (mean $=0.1$; table 2 ) because the study area included large expanses for high elevation mountain ranges, forested communities, highly populated areas, agriculture development, and other areas of low habitat value for sage-grouse that composed a large portion of our study area. For example, the Snake River Plain in southern Idaho, which contains Interstate 84 and large areas of developed private lands, may function as a barrier for sage-grouse movements between two adjoining priority areas. The Snake River Plain also has experienced significant areas of cheatgrass (Bromus tectorum) invasions and recent fire activity resulting in higher habitat loss and fragmentation in comparison to other regions across the historical range.

\section{Discussion}

The strategy currently implemented for conserving greater sage-grouse is based on designated priority areas in each of the 11 States across its range (U.S. Fish and Wildlife Service, 2013). Focusing conservation actions on a relatively small ( $<15$ percent) total area containing a large proportion of the range-wide population can have the greatest benefit with limited resources. However, continued management under normal regulations in regions surrounding priority areas can potentially lead to a spatially disjunct set of areas that retain the characteristics necessary to sustain sage-grouse populations. We assumed that the priority areas serve as a system of reserves and function within the context of island biogeography theory (MacArthur and Wilson, 1967; Wiens, 1997).

We used two primary factors, size and connectivity of priority areas, to understand how this network functions. We ranked priority areas for their relative importance within the network and identified important habitat linkages that may help maintain connected sage-grouse populations across their range. However, our approach was a simple metric based on a social theory relating importance to number of connections. The critical component to assessing viability is not just size of priority area and number of connections but how individuals are linked together to function as a viable population.

\section{Priority Areas as a Spatial Network}

Centrality measures derived from social network theory provided an interpretable analysis for characterizing the importance of priority areas within a network. Centrality measures also produced a ranking metric for identifying key areas to conserve to minimize network connectivity loss (Freeman, 2004; Blazquez-Cabrera and others, 2014). A highly centralized network is dominated by one or a few very central nodes. If these nodes are removed, the network may quickly fragment into unconnected sub-networks by isolating individual or clusters of nodes. In contrast, a less centralized network might be more resilient because many links or nodes can fail while allowing the remaining nodes to remain connected through other network paths. 
High centrality scores for 20 of 188 priority areas indicated that the network was highly centralized. Highly ranked priority areas were characterized by large size, a more central spatial location within the network, and were surrounded by many other priority areas of various sizes. The highest ranked priority area (Priority Area ID 48) was the largest and most centrally located in the network. Large size also correlates with longer boundaries that allow for more dispersal opportunity with adjacent priority areas. Similarly, a central position in the network facilitates movement to reach numerous other priority areas, thus increasing overall connectivity across the network. Loss or fragmentation of these large priority areas, or their associated connections, would have a disproportionally large influence across the entire network. Delineating priority areas with these characteristics may be important in further conservation strategies because they play a strong role in the range-wide network connectivity.

Approximately 80 percent of the priority areas scored betweenness centrality values of (near) zero despite being well-connected to surrounding priority areas. These priority areas generally were smaller and were distributed across the network surrounding the central larger priority areas. Although these individual priority areas were small, their total area contained a large amount of the habitat across the entire sage-grouse range. Their size and location likely allows them to function as stepping stones and may be critical for individuals moving from larger neighboring priority areas needed to maintain smaller sage-grouse populations (Bodin and others, 2006; Saura and others, 2014).

\section{Connectivity among Priority Areas}

Maintaining connectivity by conserving habitat between separated populations or reserves is an important strategy to mitigate against impacts of land-use change. Landscape connectivity is often assessed in the form of least-cost paths, corridors, and graph networks to identify critical habitat connections where, if severed, could potentially isolate populations (Bunn and others, 2000; Urban and Keitt, 2001; LaPoint and others, 2013). Our primary objective was to evaluate the capability of the network of priority areas to serve as a connected reserve network for sage-grouse. To do that, we also needed to produce the first range-wide landscape-scale analysis to quantify habitat quality and connectivity across their range. This approach, incorporating an effective resistance surface, enhanced our assessment of the priority area network by permitting multiple dispersal pathways and recognizing landscape heterogeneity in estimating movement cost. Our maps highlighted important habitat corridors and pinch points between priority areas that land managers can target for conservation to help ensure sage-grouse seasonal and dispersal movements. These locations also might be considered for future priority areas to ensure connectivity.

We emphasize that the parameters defining connectivity in our study were based on a habitat suitability metric measured at a $1-\mathrm{km}^{2}$ resolution. The interpretation of connectivity requires an understanding of genetic, individual, and population levels as well as recognizing behavioral differences between seasonal and dispersal movements. Connectivity to maintain genetic diversity might have different requirements than the connectivity necessary to recolonize areas or augment declining populations. Characteristics of sage-grouse dispersal are relatively unknown (Connelly and others, 2011); patterns from telemetry, satellite, and genetic studies would provide valuable information in assessing landscape-scale connectivity for conservation planning. 


\section{Relative Isolation}

The cost of movement across a landscape is a combined function of distance and resistance to movement (McRae, 2006). Connectivity, measured by the effective resistance distance, varied widely across the sage-grouse range. Some geographically distant priority areas were highly connected to the network through corridors of low resistance to movement. In contrast, other priority areas in close proximity were disconnected because of resistance created by unsuitable environments.

The formal conservation strategy focused on priority areas did not designate connecting corridors among priority areas, which could effectively isolate priority areas or regions. Therefore, we identified linkages and pinch-points that may be important for sustaining sagegrouse movements among priority areas (Bengtsson and others, 2003; Beier and others, 2011; Dickson and others, 2013; LaPoint and others, 2013). Most techniques for analyzing landscape connectivity identify one primary route based on a least cost pathway that becomes the focus for conservation efforts. Our approach for characterizing connectivity based on a resistance surface and circuit theory allowed for the quantitative and simultaneous evaluation of multiple alternative habitat linkages important for maintaining connected sage-grouse populations (McRae and others, 2008; Knick and others, 2013).

\section{Synthesis and Application}

The current network of priority areas has many important characteristics for maintaining sage-grouse populations. This network contained a range of large and small sizes of priority areas that might provide different functions. The structure of the network of priority areas for conserving greater sage-grouse was highly centralized. A relatively few large and more central priority areas accounted for a large proportion of cumulative centrality ranking. These large priority areas likely can self-sustain viable sage-grouse populations because of the large sagebrush regions within their boundaries. Large priority areas also might function as sources to augment adjacent populations, either those in priority areas too small to support persistent sagegrouse populations or in nonpriority areas.

The network also contained connected clusters of priority areas that otherwise might be too small individually to sustain viable populations. For example, a cluster of priority areas in Wyoming were highly connected and centered on one large priority area. A priority area cluster in Montana appears geographically isolated but is highly connected to the Wyoming cluster through habitat linkages in North and South Dakota. High current densities between priority areas in Oregon connect with priority areas across Idaho, Nevada, and California. The Bi-State cluster on the border of Nevada and California was isolated from all other clusters but exhibited a high degree of connectivity among the priority areas within it. Although our analysis focused on the range-wide network, there is likely a hierarchical system of networks for both priority areas and metapopulations of sage-grouse. These smaller clusters might function independently and an analysis of these smaller clusters as networks might provide important insights into regional centrality and linkages. 
Designating clustered areas in close proximity is one of the central tenets of reserve design (Diamond, 1975; Williams and others, 2004). Clustering helps to promote frequent dispersal movements for genetic exchange. Clustering also might enhance migration that might rescue declining or isolated populations, allow for seasonal movements, or egress away from areas that have become degraded or lost (Cabeza and Moilanen, 2001). Maintaining connectivity within and among the clusters potentially allows for dispersal to augment declining populations and maintain genetic exchange across the entire network reducing the chance for the creation of isolated or genetically distinct populations in the long-term (Crooks and Sanjayan, 2006).

Priority areas that scored lower in the centrality metrics were mid-sized and widely distributed across the entire range. Their function as stepping stones to reduce overall distance for sage-grouse movements among the central priority areas is an important consideration for sustaining a connected network.

Adopting a range-wide conservation plan for sage-grouse based on a network of priority areas has risks. Different conservation and management priorities among administrative units could disrupt the metapopulation structure leading to greater isolation and potentially initiate or accelerate population declines. Many priority areas share a boundary on State jurisdictional lines and many important habitat linkages presented here occur across State and Federal jurisdictional boundaries. Yet, priorities and land use plans often differ among State and Federal management agencies both within and outside of the proposed priority area structure (Copeland and others, 2014). Understanding the functions of the priority area network and recognizing the importance of connecting corridors can help sustain sage-grouse populations.

Designing reserve networks is challenging because of combined needs to protect the largest habitat or population areas in a landscape, ensure that those areas are close enough to sustain effective dispersal rates, and also ensure that a sufficient number of areas exist so that individual losses can be absorbed within the entire network (Diamond, 1975; Cabeza and Moilanen, 2001; Williams and others, 2004). Our centrality results may help predict impacts to connectivity when priority areas are lost, degraded, or fragmented. Numerous factors, both natural and anthropogenic, make it unlikely that the current network of priority areas can be sustained (Knick and Connelly, 2011). Focusing conservation actions on important and highly connected priority areas and corresponding habitat linkages may help to mitigate future landscape change and enhance the long-term viability of sage-grouse populations.

\section{Acknowledgments}

Western Association of Fish and Wildlife Agencies within the sage-grouse range provided spatial data. U.S. Geological Survey provided ancillary support. D.E. Naugle, University of Montana, was responsible for the zoo metaphor. S.L. Phillips, U.S. Geological Survey, reviewed an early draft of the manuscript. 


\section{References Cited}

Beier, P., Spencer, W., Baldwin, R., and McRae, B. H., 2011, Best science practices for developing regional connectivity maps: Conservation Biology, v. 25, p. 879-892.

Bengtsson, J., Angelstam, P., Elmqvist, T., Emanuelsson, U., Folke, C., Ihse, M., Moberg, F., and Nyström, M., 2003, Reserves, resilience and dynamic landscapes: Ambio, v. 32, p. 389396.

Blazquez-Cabrera, S., Bodin, Ö., and Saura, S., 2014, Indicators of the impacts of habitat loss on connectivity and related conservation priorities-Do they change when habitat patches are defined at different scales?: Ecological Indicators, v. 60, p. 704-716.

Bodin, Ö., and Norberg, J., 2007, A network approach for analyzing spatially structured populations in fragmented landscapes: Landscape Ecology, v. 22, p. 31-44.

Bodin, Ö., Tengö, M., Norman, A., Lundberg, J., and Elmqvist, T., 2006, The value of small size - Loss of forest patches and ecological thresholds in southern Madagascar: Ecological Applications, v. 16, p. 440-451.

Brandes, U., 2008, On variants of shortest-path betweenness centrality and their generic computation: Social Networks, v. 30, p. 136-145.

Bro, R., Acar, E., and Kolda, T.G., 2008, Resolving the sign ambiguity in the singular value decomposition: Journal of Chemometrics, v. 22, p. 135-140.

Bunn, A.G., Urban, D.L., and Keitt, T.H., 2000, Landscape connectivity-A conservation application of graph theory: Journal of Environmental Management, v. 59, p. 265-278.

Cabeza, M., and Moilanen, A., 2001, Design of reserve networks and the persistence of biodiversity: Trends in Ecology and Evolution, v. 16, p. 242-248.

Carroll, C., McRae, B., and Brookes, A., 2012, Use of linkage mapping and centrality analysis across habitat gradients to conserve connectivity of gray wolf populations in western North America: Conservation Biology, v. 26, p. 78-87.

Connelly, J.W., Rinkes, E.T., and Braun, C.E., 2011, Characteristics of sage-grouse habitats, in Knick, S.T., and Connelly, J.W., eds., Greater sage-grouse - Ecology and conservation of a landscape species and its habitats - Studies in avian biology: Berkeley, University of California Press, p. 69-83.

Copeland, H.E., Sawyer, H., Monteith, K.L., Naugle, D.E., Pocewicz, A., Graf, N., and Kauffman, M.J., 2014, Conserving migratory mule deer through the umbrella of sage-grouse:

Ecosphere, v. 5, issue 9, article 117, DOI:10.1890/ ES14-00186.1.

Crooks, K.R., and Sanjayan, M.A., 2006, Connectivity conservation: Cambridge, United Kingdom, Cambridge University Press, 712 p., DOI:10.1017/CBO9780511754821.

Csardi, G., and Nepusz, T., 2006, The igraph software package for complex network research, InterJournal, Complex Systems 1695, http://igraph.org.

Daly, C., Gibson, P., Doggett, M., Smith, J., and Taylor, G., 2004, Up-to-date climate monthly maps for the conterminous United States: Proceedings, 14th American Meteorological Society Conference on Applied Climatology, 84th American Meteorological Society Annual Meeting Combined Preprints,, January 13-16, 2004, Seattle, Washington Paper P5.1 [CD-ROM].

Diamond, J., 1975, Assembly of species communities, in Cody, M.L., and Diamond, J., eds., Ecology and evolution of communities: Cambridge, Massachusetts, Belknap Press, p. 342444.

Dickson, B.G., Roemer, G.W., McRae, B.H., and Rundall, J.M., 2013, Models of regional habitat quality and connectivity for pumas (Puma concolor) in the Southwestern United States: PLoS ONE, v. 8, e81898, DOI:10.1371/journal.pone.0081898. 
Diestel, R., 2005, Graph theory (3rd ed.): Heidelberg, Germany, Springer-Verlag, v. 173, 431 p., ISBN 3-540-26182-6.

Doherty, K.E., Tack, J.D., Evans, J.S., and Naugle, D.E., 2010, Mapping breeding densities of greater sage grouse-A tool for range-wide conservation planning: Bureau of Land Management Completion Report, Interagency Agreement \# L10PG00911.

Dunn, J.E., and Duncan, L., 2000, Partitioning Mahalanobis $\mathrm{D}^{2}$ to sharpen GIS classification, in Brebbia, C.A., and Pascolo, P., eds., Management Information Systems 2000-GIS and remote sensing: Southampton, United Kingdom, WIT Press, p. 195-204.

Erdos, P., and Gallai, T., 1960, Graphs with prescribed degrees of vertices: Matematikai Lapok, v. 11, p. 264-274 [in Hungarian].

Estrada, E., 2007, Topological structural classes of complex networks: Physical Review E, v. 75, 016103-1-016103-12.

Fedy, B.C., Doherty, K.E., Aldridge, C.L., O’Donnell, M., Beck, J.L., Bedrosian, B., Gummer, D., Holloran, M.J., Johnson, G.D., Kaczor, N.W., Kirol, C.P., Mandich, C.A., Marshall, D., Mckee, G., Olson, C., Pratt, A.C., Swanson, C.C., and Walker, B.L., 2014, Habitat prioritization across large landscapes, multiple seasons, and novel areas: an example using greater sage-grouse in Wyoming: Wildlife Monographs 190, 39 p.

Fielding, A.H., and Bell, J.F., 1997, A review of methods for the assessment of prediction errors in conservation presence/absence models: Environmental Conservation, v. 24, p. 38-49.

Freeman, L.C., 1977, A set of measures of centrality based on betweenness: Sociometry, v. 40, p. 35-41, DOI:10.2307/3033543.

Freeman, L.C., 1979, Centrality in social networks - Conceptual clarification: Social Networks, v. 1, p. 215-239.

Freeman, L.C., 2004, The development of social network analysis - A study in the sociology of science: Vancouver, British Columbia, Empirical Press, 218 p.

Freeman, L.C., Borgatti, S.P., and White, D.R., 1991, Centrality in valued graphs-A measure of betweenness based on network flow: Social Networks, v. 13, p. 41-154.

Garton, E.O., Connelly, J.W., Horne, J.S., Hagen, C.A., Moser, A., and Schroeder, M.A., 2011, Greater sage-grouse populations trends and probability of persistence, in Knick, S.T., and Connelly, J.W., eds., Greater sage-grouse-Ecology and conservation of a landscape species and its habitats: Berkeley, University of California Press, p. 293-381.

González-Pereira, B., Guerrero-Bote, V.P., and Moya-Anegón, F., 2010, A new approach to the metric of journals' scientific prestige-The SJR indicator: Journal of Informetrics, v. 4, p. 379-391.

Hanski, I., 1999, Habitat connectivity, habitat continuity and metapopulations in dynamic landscapes: Oikos, v. 87, p. 209-219.

Hanski, I., and Gilpin, M., 1991, Metapopulation dynamics-Brief history and conceptual domain: Biological Journal of the Linnean Society, v. 42, p. 3-16.

Knick, S.T., 2011, Historical development, principal federal legislation, and current management of sagebrush habitats - Implications for conservation, in Knick, S.T., and Connelly, J.W., eds., Greater sage-grouse-Ecology and conservation of a landscape species and its habitats: Berkeley, University of California Press, p. 13-31.

Knick, S.T., and Connelly, J.W., 2011, Greater sage-grouse and sagebrush-An introduction to the landscape, in Knick, S.T., and Connelly, J.W., eds., Greater sage-grouse-Ecology and conservation of a landscape species and its habitats: Berkeley, University of California Press, p. 1-9. 
Knick, S.T., Hanser, S.E., and Preston, K.L., 2013, Modeling ecological minimum requirements for distribution of greater sage-grouse leks-Implications for population connectivity across their western range, U.S.A.: Ecology and Evolution, v. 3, p. 1539-1551.

LaPoint, S., Gallery, P., Wikelski, M., and Kays, R., 2013, Animal behavior, cost-based corridor models, and real corridors: Landscape Ecology, v. 28, p. 1615-1630.

MacArthur, R.H., and Wilson, E.O., 1967, The theory of island biogeography: Princeton, New Jersey, Princeton University Press, 224 p.

McRae, B.H., 2006, Isolation by resistance: Evolution, v. 60, p. 1551-1561.

McRae, B.H., Dickson, B.G., Keitt, T.H., and Shah, V.B., 2008, Using circuit theory to model connectivity in ecology, evolution, and conservation: Ecology, v. 89, p. 2712-2724.

McRae, B.H., and Shah, V.B., 2008, Circuitscape user's guide: Santa Barbara, University of California, www.circuitscape.org/userguide.

Moreno, J.L., 1932, Application of the group method to classification: New York, National Committee on Prisons and Prison Labor, $104 \mathrm{p}$.

Moreno, J.L., 1934, Who shall survive?: Washington, D.C., Nervous and Mental Disease Publishing Company, $440 \mathrm{p}$.

Newman, M.E.J., 2010, Networks-An introduction: Oxford, United Kingdom, Oxford University Press, 784 p.

Oregon State University, 2011, PRISM digital temperature and precipitation data: PRISM Climate Group database, http://www.prism.oregonstate.edu.

R Core Team, 2013, R-A language and environment for statistical computing: Vienna, Austria, R Foundation for Statistical Computing, http://www.R-project.org/, ISBN 3-900051-07-0.

Rollins, M.G., 2009, LANDFIRE - A nationally consistent vegetation, wildland fire, and fuel assessment: International Journal of Wildland Fire, v. 18, p. 235-249.

Rotenberry, J.T., Knick, S.T., and Dunn, J.E., 2002, A minimalist approach to mapping species' habitat-Pearson's planes of closest fit, in Scott, J.M., Heglund, P.J., Morrison, M.L., Haufler, J.B., Raphael, M.G., Wall, W.A., and Samson, F.B., eds., Predicting species occurrencesIssues of accuracy and scale: Washington, D.C., Island Press, p. 281-289.

Sappington, J.M., Longshore, K.M., and Thompson, D.B., 2007, Quantifying landscape ruggedness for animal habitat analysis - A case study using desert bighorn sheep in the Mojave Desert: Journal of Wildlife Management, v. 71, p. 1419-1426.

Saura, S., Bodin, Ö., and Fortin, M.J., 2014, Stepping stones are crucial for species' longdistance dispersal and range expansion through habitat networks: Journal of Applied Ecology, v. 51, p. 171-182, DOI:10.1111/1365-2664.12179.

Schroeder, M.A., Aldridge, C.L., Apa, A.D., Bohne, J.R., Braun, C.E., Bunnell, S.D., Connelly, J.W., Deibert, P.A., Gardner, S.C., Hilliard, M.A., Kobriger, G.D., McAdam, S.M., McCarthy, C.W., McCarthy, J.J., Mitchell, D.L., Rickerson, E.V., and Stiver, S.J., 2004, Distribution of sage-grouse in North America: Condor, v. 106, p. 363-376.

Schroeder, M.A., Young, J.R., and Braun, C.E., 1999, Sage Grouse (Centrocercus urophasianus), in Poole, A., and Gill, F., eds., The birds of North America: Philadelphia, Pennsylvania, and Washington, D.C., The Academy of Natural Sciences and The American Ornithologists, p. 32.

Smith, R.E., 2013, Conserving Montana's sagebrush highway: long distance migration in sagegrouse: University of Montana, Missoula, M.S. thesis, 47 p. 
Spear, S.F., Balkenhol, N., Fortin, M.J., McRae, B.H., and Scribner, K., 2010, Use of resistance surfaces for landscape genetic studies: Considerations of parameterization and analysis: Molecular Ecology, v. 19, no. 17, p. 3,576-3,591.

Stiver, S.J., Apa, A.D., Bohne, J.R., Bunnell, S.D., Deibert, P.A., Gardner, S.C., Hilliard, M.A., McCarthy, C.W., and Schroeder, M.A., 2006, Greater sage-grouse comprehensive conservation strategy: Cheyenne, Wyoming: Western Association of Fish and Wildlife Agencies, accessed August 18, 2015, at http://wafwa.05one.net/Documents $\% 20$ and\%20Settings/37/Site\%20Documents/News/GreaterSagegrouseConservationStrategy2006.pdf.

Urban, D., and Keitt, T., 2001, Landscape connectivity-A graph-theoretic perspective: Ecology, v. 82, p. 1205-1218.

U.S. Department of Agriculture, 2011, Soil Survey staff-Natural Resources Conservation Service: U.S. Department of Agriculture General Soils Map (STATSGO) database, accessed December 28, 2011, at http://soildatamart.nrcs.usda.gov.

U.S. Fish and Wildlife Service, 2010, Endangered and threatened wildlife and plants; 12-month findings for petitions to list the greater sage-grouse (Centrocercus urophasianus) as threatened or endangered: Federal Register, v. 75, no. 55, p. 13909-14014, accessed August 2015, at https://www.federalregister.gov/articles/2010/03/23/2010-5132/endangered-and-threatenedwildlife-and-plants-12-month-findings-for-petitions-to-list-the-greater.

U.S. Fish and Wildlife Service, 2013, Greater sage-grouse (Centrocercus urophasianus) conservation objectives - Final report: U.S. Fish and Wildlife Service, Denver, Colorado.

Wasserman, S., and Faust, K., 2004, Social network analysis-Methods and applications: Cambridge, United Kingdom, and New York, Cambridge University Press, 857 p.

Wiens, J.A., 1997, Metapopulation dynamics and landscape ecology, in Hanski, I., and Gilpin, M., eds., Metapopulation dynamics - Ecology, genetics, and evolution: New York, Academic Press, p. 43-62.

Williams, J.C., ReVelle, C.S., and Levin, S.A., 2004, Using mathematical optimization models to design nature reserves: Frontiers in Ecology and the Environment, v. 2, p. 98-105, DOI:10.1890/1540-9295(2004)002[0098:UMOMTD]2.0.CO;2.

Zeller, K.A., McGarigal, K., and Whiteley, A.R., 2012, Estimating landscape resistance to movement: a review: Landscape Ecology, v. 27, p. 777-797. 
This page left intentionally blank 


\section{Appendix A. Crosswalk Table Depicting Priority Area Identifiers, U.S. Fish and Wildlife Service Unique Identifiers, Sage-Grouse Population Name, and Management Zone}

[Data for crosswalk table was obtained from the U.S. Fish and Wildlife Service (FWS). ID, identifier]

\begin{tabular}{|c|c|c|c|c|}
\hline $\begin{array}{c}\text { Priority Area } \\
\text { ID }\end{array}$ & $\begin{array}{c}\text { FWS Unique } \\
\text { ID }\end{array}$ & Sage-grouse Population & $\begin{array}{c}\text { Management } \\
\text { Zone }\end{array}$ & FWS Name \\
\hline 1 & 401 & Bi-State & MZ3 & 401-Bi-State-MZ3 \\
\hline 2 & 395 & Bi-State & MZ3 & 395-Bi-State-MZ3 \\
\hline 3 & 358 & Bi-State & MZ3 & 358-Bi-State-MZ3 \\
\hline 4 & 396 & Bi-State & MZ3 & 396-Bi-State-MZ3 \\
\hline 5 & 334 & Parachute Piceance Roan & MZ7 & 334-Parachute Piceance Roan-MZ7 \\
\hline 6 & 353 & Bi-State & MZ3 & 353-Bi-State-MZ3 \\
\hline 7 & 354 & Bi-State & $\mathrm{MZ3}$ & 354-Bi-State-MZ3 \\
\hline 8 & 332 & Parachute Piceance Roan & MZ7 & 332-Parachute Piceance Roan-MZ7 \\
\hline 9 & 352 & Bi-State & MZ3 & 352-Bi-State-MZ3 \\
\hline 10 & 351 & Bi-State & MZ3 & 351-Bi-State-MZ3 \\
\hline 11 & 385 & Bi-State & MZ3 & 385-Bi-State-MZ3 \\
\hline 12 & 362 & Bi-State & MZ3 & 362-Bi-State-MZ3 \\
\hline 13 & 399 & Bi-State & MZ3 & 399-Bi-State-MZ3 \\
\hline 14 & 360 & Bi-State & MZ3 & 360-Bi-State-MZ3 \\
\hline 15 & 350 & Bi-State & $\mathrm{MZ3}$ & 350-Bi-State-MZ3 \\
\hline 16 & 388 & Bi-State & MZ3 & 388-Bi-State-MZ3 \\
\hline 17 & 391 & Bi-State & MZ3 & 391-Bi-State-MZ3 \\
\hline 18 & 390 & Bi-State & $\mathrm{MZ3}$ & 390-Bi-State-MZ3 \\
\hline 19 & 345 & Bi-State & MZ3 & 345-Bi-State-MZ3 \\
\hline 20 & 386 & Bi-State & MZ3 & 386-Bi-State-MZ3 \\
\hline 21 & 349 & Bi-State & $\mathrm{MZ3}$ & 349-Bi-State-MZ3 \\
\hline 22 & 383 & Bi-State & MZ3 & 383-Bi-State-MZ3 \\
\hline 23 & 387 & Bi-State & MZ3 & 387-Bi-State-MZ3 \\
\hline 24 & 356 & Bi-State & MZ3 & 356-Bi-State-MZ3 \\
\hline 25 & 355 & Bi-State & MZ3 & 355-Bi-State-MZ3 \\
\hline 26 & 357 & Bi-State & MZ3 & 357-Bi-State-MZ3 \\
\hline 27 & 359 & Bi-State & $\mathrm{MZ3}$ & 359-Bi-State-MZ3 \\
\hline 28 & 394 & Bi-State & MZ3 & 394-Bi-State-MZ3 \\
\hline 29 & 393 & Bi-State & $\mathrm{MZ3}$ & 393-Bi-State-MZ3 \\
\hline 30 & 382 & Bi-State & $\mathrm{MZ3}$ & 382-Bi-State-MZ3 \\
\hline 31 & 389 & Bi-State & MZ3 & 389-Bi-State-MZ3 \\
\hline 32 & 384 & Bi-State & $\mathrm{MZ3}$ & 384-Bi-State-MZ3 \\
\hline 33 & 381 & Bi-State & $\mathrm{MZ3}$ & 381-Bi-State-MZ3 \\
\hline 34 & 374 & Bi-State & $\mathrm{MZ3}$ & 374-Bi-State-MZ3 \\
\hline 35 & 344 & Bi-State & $\mathrm{MZ3}$ & 344-Bi-State-MZ3 \\
\hline 36 & 369 & Bi-State & MZ3 & 369-Bi-State-MZ3 \\
\hline
\end{tabular}




\begin{tabular}{|c|c|c|c|c|}
\hline $\begin{array}{l}\text { Priority Area } \\
\text { ID }\end{array}$ & $\begin{array}{l}\text { FWS Unique } \\
\text { ID }\end{array}$ & Sage-grouse Population & $\begin{array}{l}\text { Management } \\
\text { Zone }\end{array}$ & FWS Name \\
\hline 37 & 372 & Bi-State & MZ3 & 372-Bi-State-MZ3 \\
\hline 38 & 370 & Bi-State & MZ3 & 370-Bi-State-MZ3 \\
\hline 39 & 341 & Bi-State & MZ3 & 341-Bi-State-MZ3 \\
\hline 40 & 347 & Bi-State & MZ3 & 347-Bi-State-MZ3 \\
\hline 41 & 346 & Bi-State & MZ3 & 346-Bi-State-MZ3 \\
\hline 42 & 375 & Bi-State & MZ3 & 375-Bi-State-MZ3 \\
\hline 43 & 314 & Western Great Basin & MZ5 & 314-Western Great Basin-MZ5 \\
\hline 44 & 343 & Bi-State & MZ3 & 343-Bi-State-MZ3 \\
\hline 45 & 317 & Klamath OR/CA & MZ5 & 317-Klamath OR/CA-MZ5 \\
\hline 46 & 368 & Bi-State & MZ3 & 368-Bi-State-MZ3 \\
\hline 47 & 367 & Bi-State & MZ3 & 367-Bi-State-MZ3 \\
\hline 48 & 316 & Western Great Basin & MZ5 & 316-Western Great Basin-MZ5 \\
\hline 49 & 309 & Western Great Basin & MZ5 & 309-Western Great Basin-MZ5 \\
\hline 50 & 312 & Western Great Basin & MZ5 & 312-Western Great Basin-MZ5 \\
\hline 51 & 223 & Eagle/S Routt CO & MZ2 & 223-Eagle/S Routt CO-MZ2 \\
\hline 52 & 156 & Wyoming Basin & MZ2 & 156-Wyoming Basin-MZ2 \\
\hline 53 & 363 & Bi-State & MZ3 & 363-Bi-State-MZ3 \\
\hline 54 & 306 & Central & MZ5 & 306-Central-MZ5 \\
\hline 55 & 322 & Yakama Indian Nation & MZ6 & 322-Yakama Indian Nation-MZ6 \\
\hline 56 & 253 & $\begin{array}{l}\text { Snake, Salmon, and } \\
\text { Beaverhead }\end{array}$ & MZ4 & $\begin{array}{l}\text { 253-Snake, Salmon, and } \\
\text { Beaverhead-MZ4 }\end{array}$ \\
\hline 57 & 279 & Northern Great Basin & MZ4 & 279-Northern Great Basin-MZ4 \\
\hline 58 & 329 & Parachute Piceance Roan & MZ7 & 329-Parachute Piceance Roan-MZ7 \\
\hline 59 & 340 & Parachute Piceance Roan & MZ7 & 340-Parachute Piceance Roan-MZ7 \\
\hline 60 & 331 & Parachute Piceance Roan & MZ7 & 331-Parachute Piceance Roan-MZ7 \\
\hline 61 & 224 & Eagle/S Routt CO & MZ2 & 224-Eagle/S Routt CO-MZ2 \\
\hline 62 & 239 & Panguitch & MZ3 & 239-Panguitch-MZ3 \\
\hline 63 & 398 & Bi-State & MZ3 & 398-Bi-State-MZ3 \\
\hline 64 & 242 & Southern Great Basin & MZ3 & 242-Southern Great Basin-MZ3 \\
\hline 65 & 243 & Southern Great Basin & MZ3 & 243-Southern Great Basin-MZ3 \\
\hline 66 & 241 & Southern Great Basin & MZ3 & 241-Southern Great Basin-MZ3 \\
\hline 67 & 232 & Sheeprock Mountains & MZ3 & 232-Sheeprock Mountains-MZ3 \\
\hline 68 & 237 & Carbon & MZ3 & 237-Carbon-MZ3 \\
\hline 69 & 361 & Bi-State & MZ3 & 361-Bi-State-MZ3 \\
\hline 70 & 400 & Bi-State & MZ3 & 400-Bi-State-MZ3 \\
\hline 71 & 214 & Middle Park CO & MZ2 & 214-Middle Park CO-MZ2 \\
\hline 72 & 221 & Eagle/S Routt CO & MZ2 & 221-Eagle/S Routt CO-MZ2 \\
\hline 73 & 222 & Eagle/S Routt CO & MZ2 & 222-Eagle/S Routt CO-MZ2 \\
\hline 74 & 220 & Eagle/S Routt CO & MZ2 & 220-Eagle/S Routt CO-MZ2 \\
\hline 75 & 326 & Meeker - White River & MZ7 & 326-Meeker - White River-MZ7 \\
\hline 76 & 327 & Parachute Piceance Roan & MZ7 & 327-Parachute Piceance Roan-MZ7 \\
\hline 77 & 323 & Meeker - White River & MZ7 & 323-Meeker - White River-MZ7 \\
\hline
\end{tabular}




\begin{tabular}{|c|c|c|c|c|}
\hline $\begin{array}{c}\text { Priority Area } \\
\text { ID }\end{array}$ & $\begin{array}{l}\text { FWS Unique } \\
\text { ID }\end{array}$ & Sage-grouse Population & $\begin{array}{l}\text { Management } \\
\text { Zone }\end{array}$ & FWS Name \\
\hline 78 & 238 & Parker Mountain-Emery & MZ3 & 238-Parker Mountain-Emery-MZ3 \\
\hline 79 & 153 & Wyoming Basin & MZ2 & 153-Wyoming Basin-MZ2 \\
\hline 80 & 152 & Wyoming Basin & MZ2 & 152-Wyoming Basin-MZ2 \\
\hline 81 & 235 & Strawberry & MZ3 & 235-Strawberry-MZ3 \\
\hline 82 & 154 & Wyoming Basin & MZ2 & 154-Wyoming Basin-MZ2 \\
\hline 83 & 183 & Wyoming Basin & MZ2 & 183-Wyoming Basin-MZ2 \\
\hline 84 & 219 & Eagle/S Routt CO & MZ2 & 219-Eagle/S Routt CO-MZ2 \\
\hline 85 & 204 & Wyoming Basin & MZ2 & 204-Wyoming Basin-MZ2 \\
\hline 86 & 198 & Wyoming Basin & MZ2 & 198-Wyoming Basin-MZ2 \\
\hline 87 & 160 & Wyoming Basin & MZ2 & 160-Wyoming Basin-MZ2 \\
\hline 88 & 193 & Wyoming Basin & MZ2 & 193-Wyoming Basin-MZ2 \\
\hline 89 & 199 & Wyoming Basin & MZ2 & 199-Wyoming Basin-MZ2 \\
\hline 90 & 195 & Wyoming Basin & MZ2 & 195-Wyoming Basin-MZ2 \\
\hline 91 & 158 & Wyoming Basin & MZ2 & 158-Wyoming Basin-MZ2 \\
\hline 92 & 191 & Wyoming Basin & MZ2 & 191-Wyoming Basin-MZ2 \\
\hline 93 & 182 & Wyoming Basin & MZ2 & 182-Wyoming Basin-MZ2 \\
\hline 94 & 266 & $\begin{array}{l}\text { Snake, Salmon, and } \\
\text { Beaverhead }\end{array}$ & MZ4 & $\begin{array}{l}\text { 266-Snake, Salmon, and } \\
\text { Beaverhead-MZ4 }\end{array}$ \\
\hline 95 & 213 & North Park & MZ2 & 213-North Park-MZ2 \\
\hline 96 & 142 & Wyoming Basin & MZ2 & 142-Wyoming Basin-MZ2 \\
\hline 97 & 159 & Wyoming Basin & MZ2 & 159-Wyoming Basin-MZ2 \\
\hline 98 & 157 & Wyoming Basin & MZ2 & 157-Wyoming Basin-MZ2 \\
\hline 99 & 178 & Wyoming Basin & MZ2 & 178-Wyoming Basin-MZ2 \\
\hline 100 & 169 & Wyoming Basin & MZ2 & 169-Wyoming Basin-MZ2 \\
\hline 101 & 139 & Wyoming Basin & MZ2 & 139-Wyoming Basin-MZ2 \\
\hline 102 & 143 & Wyoming Basin & MZ2 & 143-Wyoming Basin-MZ2 \\
\hline 103 & 114 & Powder River Basin & MZ1 & 114-Powder River Basin-MZ1 \\
\hline 104 & 141 & Wyoming Basin & MZ2 & 141-Wyoming Basin-MZ2 \\
\hline 105 & 148 & Wyoming Basin & MZ2 & 148-Wyoming Basin-MZ2 \\
\hline 106 & 150 & Wyoming Basin & MZ2 & 150-Wyoming Basin-MZ2 \\
\hline 107 & 264 & $\begin{array}{l}\text { Snake, Salmon, and } \\
\text { Beaverhead }\end{array}$ & MZ4 & $\begin{array}{l}\text { 264-Snake, Salmon, and } \\
\text { Beaverhead-MZ4 }\end{array}$ \\
\hline 108 & 144 & Wyoming Basin & MZ2 & 144-Wyoming Basin-MZ2 \\
\hline 109 & 149 & Wyoming Basin & MZ2 & 149-Wyoming Basin-MZ2 \\
\hline 110 & 145 & Wyoming Basin & MZ2 & 145-Wyoming Basin-MZ2 \\
\hline 111 & 146 & Wyoming Basin & MZ2 & 146-Wyoming Basin-MZ2 \\
\hline 112 & 366 & Bi-State & MZ3 & 366-Bi-State-MZ3 \\
\hline 113 & 244 & NW-Interior NV & MZ3 & 244-NW-Interior NV-MZ3 \\
\hline 114 & 267 & $\begin{array}{l}\text { Snake, Salmon, and } \\
\text { Beaverhead }\end{array}$ & MZ4 & $\begin{array}{l}\text { 267-Snake, Salmon, and } \\
\text { Beaverhead-MZ4 }\end{array}$ \\
\hline 115 & 263 & $\begin{array}{l}\text { Snake, Salmon, and } \\
\text { Beaverhead }\end{array}$ & MZ4 & $\begin{array}{l}\text { 263-Snake, Salmon, and } \\
\text { Beaverhead-MZ4 }\end{array}$ \\
\hline 116 & 138 & Wyoming Basin & MZ2 & 138-Wyoming Basin-MZ2 \\
\hline
\end{tabular}




\begin{tabular}{|c|c|c|c|c|}
\hline $\begin{array}{l}\text { Priority Area } \\
\text { ID }\end{array}$ & $\begin{array}{l}\text { FWS Unique } \\
\text { ID }\end{array}$ & Sage-grouse Population & $\begin{array}{l}\text { Management } \\
\text { Zone }\end{array}$ & FWS Name \\
\hline 117 & 126 & Jackson Hole WY & MZ2 & 126-Jackson Hole WY-MZ2 \\
\hline 118 & 246 & Southwest Montana & MZ4 & 246-Southwest Montana-MZ4 \\
\hline 119 & 245 & Southwest Montana & MZ4 & 245-Southwest Montana-MZ4 \\
\hline 120 & 275 & Northern Great Basin & MZ4 & 275-Northern Great Basin-MZ4 \\
\hline 121 & 273 & Northern Great Basin & MZ4 & 273-Northern Great Basin-MZ4 \\
\hline 122 & 248 & $\begin{array}{l}\text { Snake, Salmon, and } \\
\text { Beaverhead }\end{array}$ & MZ4 & $\begin{array}{l}\text { 248-Snake, Salmon, and } \\
\text { Beaverhead-MZ4 }\end{array}$ \\
\hline 123 & 269 & Northern Great Basin & MZ4 & 269-Northern Great Basin-MZ4 \\
\hline 124 & 277 & Northern Great Basin & MZ4 & 277-Northern Great Basin-MZ4 \\
\hline 125 & 310 & Western Great Basin & MZ5 & 310-Western Great Basin-MZ5 \\
\hline 126 & 247 & Southwest Montana & MZ4 & 247-Southwest Montana-MZ4 \\
\hline 127 & 115 & Powder River Basin & MZ1 & 115-Powder River Basin-MZ1 \\
\hline 128 & 121 & Powder River Basin & MZ1 & 121-Powder River Basin-MZ1 \\
\hline 129 & 108 & Yellowstone Watershed & MZ1 & 108-Yellowstone Watershed-MZ1 \\
\hline 130 & 147 & Wyoming Basin & MZ2 & 147-Wyoming Basin-MZ2 \\
\hline 131 & 104 & Yellowstone Watershed & MZ1 & 104-Yellowstone Watershed-MZ1 \\
\hline 132 & 117 & Powder River Basin & MZ1 & 117-Powder River Basin-MZ1 \\
\hline 133 & 137 & Wyoming Basin & MZ2 & 137-Wyoming Basin-MZ2 \\
\hline 134 & 106 & Yellowstone Watershed & MZ1 & 106-Yellowstone Watershed-MZ1 \\
\hline 135 & 116 & Powder River Basin & MZ1 & 116-Powder River Basin-MZ1 \\
\hline 136 & 120 & Powder River Basin & MZ1 & 120-Powder River Basin-MZ1 \\
\hline 137 & 107 & Yellowstone Watershed & MZ1 & 107-Yellowstone Watershed-MZ1 \\
\hline 138 & 110 & Yellowstone Watershed & MZ1 & 110-Yellowstone Watershed-MZ1 \\
\hline 139 & 119 & Powder River Basin & MZ1 & 119-Powder River Basin-MZ1 \\
\hline 140 & 123 & Powder River Basin & MZ1 & 123-Powder River Basin-MZ1 \\
\hline 141 & 135 & Wyoming Basin & MZ2 & 135-Wyoming Basin-MZ2 \\
\hline 142 & 134 & Wyoming Basin & MZ2 & 134-Wyoming Basin-MZ2 \\
\hline 143 & 128 & Wyoming Basin & MZ2 & 128-Wyoming Basin-MZ2 \\
\hline 144 & 130 & Wyoming Basin & MZ2 & 130-Wyoming Basin-MZ2 \\
\hline 145 & 105 & Yellowstone Watershed & MZ1 & 105-Yellowstone Watershed-MZ1 \\
\hline 146 & 102 & Northern Montana & MZ1 & 102-Northern Montana-MZ1 \\
\hline 147 & 113 & Dakotas & MZ1 & 113-Dakotas-MZ1 \\
\hline 148 & 118 & Powder River Basin & MZ1 & 118-Powder River Basin-MZ1 \\
\hline 149 & 305 & Central & MZ5 & 305-Central-MZ5 \\
\hline 150 & 101 & Northern Montana & MZ1 & 101-Northern Montana-MZ1 \\
\hline 151 & 111 & Dakotas & MZ1 & 111-Dakotas-MZ1 \\
\hline 152 & 321 & Yakama Training Center & MZ6 & 321-Yakama Training Center-MZ6 \\
\hline 153 & 397 & Bi-State & MZ3 & 397-Bi-State-MZ3 \\
\hline 154 & 392 & Bi-State & MZ3 & 392-Bi-State-MZ3 \\
\hline 155 & 365 & Bi-State & MZ3 & 365-Bi-State-MZ3 \\
\hline 156 & 380 & Bi-State & MZ3 & 380-Bi-State-MZ3 \\
\hline 157 & 379 & Bi-State & MZ3 & 379-Bi-State-MZ3 \\
\hline
\end{tabular}




\begin{tabular}{|c|c|c|c|c|}
\hline $\begin{array}{l}\text { Priority Area } \\
\text { ID }\end{array}$ & $\begin{array}{l}\text { FWS Unique } \\
\text { ID }\end{array}$ & Sage-grouse Population & $\begin{array}{l}\text { Management } \\
\text { Zone }\end{array}$ & FWS Name \\
\hline 158 & 377 & Bi-State & MZ3 & 377-Bi-State-MZ3 \\
\hline 159 & 378 & Bi-State & MZ3 & 378-Bi-State-MZ3 \\
\hline 160 & 348 & Bi-State & MZ3 & 348-Bi-State-MZ3 \\
\hline 161 & 376 & Bi-State & MZ3 & 376-Bi-State-MZ3 \\
\hline 162 & 373 & Bi-State & MZ3 & 373-Bi-State-MZ3 \\
\hline 163 & 371 & Bi-State & MZ3 & 371-Bi-State-MZ3 \\
\hline 164 & 364 & Bi-State & MZ3 & 364-Bi-State-MZ3 \\
\hline 165 & 342 & Bi-State & MZ3 & 342-Bi-State-MZ3 \\
\hline 166 & 308 & Western Great Basin & MZ5 & 308-Western Great Basin-MZ5 \\
\hline 167 & 270 & Northern Great Basin & MZ4 & 270-Northern Great Basin-MZ4 \\
\hline 168 & 276 & Northern Great Basin & MZ4 & 276-Northern Great Basin-MZ4 \\
\hline 169 & 272 & Northern Great Basin & MZ4 & 272-Northern Great Basin-MZ4 \\
\hline 170 & 274 & Northern Great Basin & MZ4 & 274-Northern Great Basin-MZ4 \\
\hline 171 & 304 & Central & MZ5 & 304-Central-MZ5 \\
\hline 172 & 300 & Central & MZ5 & 300-Central-MZ5 \\
\hline 173 & 302 & Central & MZ5 & 302-Central-MZ5 \\
\hline 174 & 271 & Northern Great Basin & MZ4 & 271-Northern Great Basin-MZ4 \\
\hline 175 & 303 & Central & MZ5 & 303-Central-MZ5 \\
\hline 176 & 301 & Central & MZ5 & 301-Central-MZ5 \\
\hline 177 & 268 & Baker & MZ4 & 268-Baker-MZ4 \\
\hline 178 & 320 & Crab Creek & MZ6 & 320-Crab Creek-MZ6 \\
\hline 179 & 319 & Moses Coulee & MZ6 & 319-Moses Coulee-MZ6 \\
\hline 180 & 298 & Northern Great Basin & MZ4 & 298-Northern Great Basin-MZ4 \\
\hline 181 & 140 & Wyoming Basin & MZ2 & 140-Wyoming Basin-MZ2 \\
\hline 182 & 136 & Wyoming Basin & MZ2 & 136-Wyoming Basin-MZ2 \\
\hline 183 & 132 & Wyoming Basin & MZ2 & 132-Wyoming Basin-MZ2 \\
\hline 184 & 131 & Wyoming Basin & MZ2 & 131-Wyoming Basin-MZ2 \\
\hline 185 & 129 & Wyoming Basin & MZ2 & 129-Wyoming Basin-MZ2 \\
\hline 186 & 133 & Wyoming Basin & MZ2 & 133-Wyoming Basin-MZ2 \\
\hline 187 & 315 & Western Great Basin & MZ5 & 315-Western Great Basin-MZ5 \\
\hline 188 & 288 & Northern Great Basin & MZ4 & 288-Northern Great Basin-MZ4 \\
\hline
\end{tabular}




\section{Appendix B. Centrality Results for Degree and Betweenness Metrics for Each Priority Area}

[Priority areas are ranked from highest to lowest betweenness centrality value. Cumulative percent of betweenness centrality was calculated to provide each priority area's contribution to total betweenness centrality. ID, identifier]

\begin{tabular}{|c|c|c|c|c|c|}
\hline $\begin{array}{l}\text { Priority Area } \\
\text { ID }\end{array}$ & $\begin{array}{l}\text { Area } \\
\left(\mathrm{km}^{2}\right)\end{array}$ & $\begin{array}{c}\text { Degree } \\
\text { Centrality }\end{array}$ & $\begin{array}{l}\text { Betweenness } \\
\text { Centrality }\end{array}$ & $\begin{array}{c}\text { Betweenness } \\
\text { Centrality Rank }\end{array}$ & $\begin{array}{c}\text { Cumulative } \\
\text { Percent }\end{array}$ \\
\hline 48 & 78,218 & 50 & 11,414 & 1 & 12.8 \\
\hline 110 & 7,673 & 20 & 6,820 & 2 & 20.4 \\
\hline 101 & 18,607 & 24 & 6,740 & 3 & 27.9 \\
\hline 39 & 440 & 22 & 5,537 & 4 & 34.1 \\
\hline 111 & 608 & 8 & 5,178 & 5 & 39.9 \\
\hline 19 & 1,847 & 32 & 5,072 & 6 & 45.6 \\
\hline 35 & 717 & 24 & 5,048 & 7 & 51.3 \\
\hline 83 & 7,316 & 48 & 4,455 & 8 & 56.2 \\
\hline 65 & 33,892 & 26 & 3,000 & 9 & 59.6 \\
\hline 181 & 11,999 & 24 & 2,554 & 10 & 62.5 \\
\hline 21 & 40 & 16 & 2,415 & 11 & 65.2 \\
\hline 114 & 9,548 & 14 & 2,024 & 12 & 67.4 \\
\hline 107 & 6,133 & 18 & 2,009 & 13 & 69.7 \\
\hline 166 & 2,570 & 18 & 1,907 & 14 & 71.8 \\
\hline 20 & 24 & 16 & 1,400 & 15 & 73.4 \\
\hline 80 & 5,593 & 22 & 1,291 & 16 & 74.8 \\
\hline 169 & 1,760 & 14 & 1,093 & 17 & 76.0 \\
\hline 105 & 950 & 10 & 1,068 & 18 & 77.2 \\
\hline 58 & 839 & 28 & 1,048 & 19 & 78.4 \\
\hline 109 & 753 & 8 & 1,029 & 20 & 79.6 \\
\hline 160 & 560 & 18 & 992 & 21 & 80.7 \\
\hline 7 & 132 & 14 & 961 & 22 & 81.7 \\
\hline 69 & 33 & 12 & 948 & 23 & 82.8 \\
\hline 148 & 493 & 8 & 945 & 24 & 83.9 \\
\hline 138 & 7,677 & 16 & 926 & 25 & 84.9 \\
\hline 182 & 2,601 & 10 & 794 & 26 & 85.8 \\
\hline 131 & 4,448 & 16 & 711 & 27 & 86.6 \\
\hline 119 & 1,894 & 14 & 670 & 28 & 87.3 \\
\hline 137 & 7,376 & 20 & 626 & 29 & 88.0 \\
\hline 167 & 1,132 & 6 & 577 & 30 & 88.7 \\
\hline 14 & 48 & 14 & 574 & 31 & 89.3 \\
\hline 98 & 554 & 10 & 542 & 32 & 89.9 \\
\hline 176 & 1,788 & 18 & 524 & 33 & 90.5 \\
\hline 9 & 82 & 12 & 491 & 34 & 91.1 \\
\hline 3 & 400 & 22 & 458 & 35 & 91.6 \\
\hline 123 & 1,492 & 16 & 400 & 36 & 92.0 \\
\hline
\end{tabular}




\begin{tabular}{|c|c|c|c|c|c|}
\hline $\begin{array}{l}\text { Priority Area } \\
\text { ID }\end{array}$ & $\begin{array}{l}\text { Area } \\
\left(\mathrm{km}^{2}\right)\end{array}$ & $\begin{array}{c}\text { Degree } \\
\text { Centrality }\end{array}$ & $\begin{array}{l}\text { Betweenness } \\
\text { Centrality }\end{array}$ & $\begin{array}{c}\text { Betweenness } \\
\text { Centrality Rank }\end{array}$ & $\begin{array}{c}\text { Cumulative } \\
\text { Percent }\end{array}$ \\
\hline 64 & 5,783 & 10 & 366 & 37 & 92.4 \\
\hline 125 & 1,336 & 14 & 366 & 38 & 92.8 \\
\hline 171 & 56 & 10 & 364 & 39 & 93.3 \\
\hline 141 & 585 & 10 & 338 & 40 & 93.6 \\
\hline 74 & 50 & 10 & 325 & 41 & 94.0 \\
\hline 157 & 2 & 16 & 295 & 42 & 94.3 \\
\hline 134 & 1,422 & 8 & 268 & 43 & 94.6 \\
\hline 62 & 4,606 & 8 & 257 & 44 & 94.9 \\
\hline 6 & 541 & 14 & 233 & 45 & 95.2 \\
\hline 133 & 1,260 & 10 & 225 & 46 & 95.4 \\
\hline 177 & 1,362 & 14 & 222 & 47 & 95.7 \\
\hline 118 & 3,264 & 12 & 218 & 48 & 95.9 \\
\hline 24 & 82 & 12 & 210 & 49 & 96.2 \\
\hline 78 & 4,563 & 12 & 210 & 50 & 96.4 \\
\hline 144 & 2,464 & 18 & 199 & 51 & 96.6 \\
\hline 139 & 3,122 & 14 & 198 & 52 & 96.8 \\
\hline 170 & 669 & 16 & 193 & 53 & 97.0 \\
\hline 178 & 3,273 & 12 & 193 & 54 & 97.3 \\
\hline 122 & 316 & 14 & 192 & 55 & 97.5 \\
\hline 146 & 6,796 & 10 & 185 & 56 & 97.7 \\
\hline 72 & 37 & 12 & 180 & 57 & 97.9 \\
\hline 95 & 1,529 & 10 & 178 & 58 & 98.1 \\
\hline 120 & 336 & 10 & 174 & 59 & 98.3 \\
\hline 135 & 284 & 10 & 172 & 60 & 98.5 \\
\hline 55 & 1,285 & 8 & 164 & 61 & 98.7 \\
\hline 142 & 147 & 8 & 155 & 62 & 98.8 \\
\hline 27 & 26 & 14 & 149 & 63 & 99.0 \\
\hline 68 & 1,442 & 14 & 148 & 64 & 99.2 \\
\hline 185 & 523 & 10 & 142 & 65 & 99.3 \\
\hline 61 & 81 & 10 & 128 & 66 & 99.5 \\
\hline 10 & 120 & 12 & 60 & 67 & 99.5 \\
\hline 33 & 23 & 12 & 60 & 68 & 99.6 \\
\hline 84 & 214 & 12 & 60 & 69 & 99.7 \\
\hline 112 & 24 & 12 & 51 & 70 & 99.7 \\
\hline 158 & 17 & 14 & 38 & 71 & 99.8 \\
\hline 25 & 24 & 12 & 30 & 72 & 99.8 \\
\hline 143 & 1,487 & 12 & 29 & 73 & 99.8 \\
\hline 121 & 227 & 8 & 24 & 74 & 99.9 \\
\hline 12 & 14 & 12 & 23 & 75 & 99.9 \\
\hline 127 & 79 & 12 & 18 & 76 & 99.9 \\
\hline 26 & 82 & 12 & 16 & 77 & 99.9 \\
\hline
\end{tabular}




\begin{tabular}{|c|c|c|c|c|c|}
\hline $\begin{array}{l}\text { Priority Area } \\
\text { ID }\end{array}$ & $\begin{array}{l}\text { Area } \\
\left(\mathrm{km}^{2}\right)\end{array}$ & $\begin{array}{c}\text { Degree } \\
\text { Centrality }\end{array}$ & $\begin{array}{l}\text { Betweenness } \\
\text { Centrality }\end{array}$ & $\begin{array}{c}\text { Betweenness } \\
\text { Centrality Rank }\end{array}$ & $\begin{array}{c}\text { Cumulative } \\
\text { Percent }\end{array}$ \\
\hline 161 & 4 & 10 & 14 & 78 & 99.9 \\
\hline 129 & 965 & 12 & 13 & 79 & 100.0 \\
\hline 184 & 661 & 8 & 12 & 80 & 100.0 \\
\hline 162 & 2 & 10 & 7 & 81 & 100.0 \\
\hline 174 & 1,492 & 14 & 7 & 82 & 100.0 \\
\hline 51 & 27 & 10 & 6 & 83 & 100.0 \\
\hline 81 & 1,309 & 10 & 4 & 84 & 100.0 \\
\hline 71 & 888 & 10 & 3 & 85 & 100.0 \\
\hline 108 & 117 & 8 & 3 & 86 & 100.0 \\
\hline 152 & 1,933 & 8 & 2 & 87 & 100.0 \\
\hline 86 & 8 & 8 & 1 & 88 & 100.0 \\
\hline 91 & 78 & 8 & 1 & 89 & 100.0 \\
\hline 175 & 81 & 8 & 1 & 90 & 100.0 \\
\hline 1 & 2 & 6 & 0 & 91 & 100.0 \\
\hline 2 & 1 & 4 & 0 & 92 & 100.0 \\
\hline 4 & 1 & 6 & 0 & 93 & 100.0 \\
\hline 5 & 5 & 6 & 0 & 94 & 100.0 \\
\hline 8 & 8 & 10 & 0 & 95 & 100.0 \\
\hline 11 & 4 & 8 & 0 & 96 & 100.0 \\
\hline 13 & 4 & 4 & 0 & 97 & 100.0 \\
\hline 15 & 153 & 12 & 0 & 98 & 100.0 \\
\hline 16 & 1 & 12 & 0 & 99 & 100.0 \\
\hline 17 & 2 & 8 & 0 & 100 & 100.0 \\
\hline 18 & 4 & 8 & 0 & 101 & 100.0 \\
\hline 22 & 2 & 12 & 0 & 102 & 100.0 \\
\hline 23 & 7 & 6 & 0 & 103 & 100.0 \\
\hline 28 & 2 & 12 & 0 & 104 & 100.0 \\
\hline 29 & 2 & 6 & 0 & 105 & 100.0 \\
\hline 30 & 2 & 8 & 0 & 106 & 100.0 \\
\hline 31 & 3 & 6 & 0 & 107 & 100.0 \\
\hline 32 & 2 & 2 & 0 & 108 & 100.0 \\
\hline 34 & 1 & 4 & 0 & 109 & 100.0 \\
\hline 36 & 2 & 10 & 0 & 110 & 100.0 \\
\hline 37 & 5 & 12 & 0 & 111 & 100.0 \\
\hline 38 & 5 & 6 & 0 & 112 & 100.0 \\
\hline 40 & 27 & 8 & 0 & 113 & 100.0 \\
\hline 41 & 15 & 8 & 0 & 114 & 100.0 \\
\hline 42 & 3 & 10 & 0 & 115 & 100.0 \\
\hline 43 & 103 & 4 & 0 & 116 & 100.0 \\
\hline 44 & 5 & 2 & 0 & 117 & 100.0 \\
\hline 45 & 658 & 10 & 0 & 118 & 100.0 \\
\hline
\end{tabular}




\begin{tabular}{|c|c|c|c|c|c|}
\hline $\begin{array}{l}\text { Priority Area } \\
\text { ID }\end{array}$ & $\begin{array}{l}\text { Area } \\
\left(\mathrm{km}^{2}\right)\end{array}$ & $\begin{array}{c}\text { Degree } \\
\text { Centrality }\end{array}$ & $\begin{array}{l}\text { Betweenness } \\
\text { Centrality }\end{array}$ & $\begin{array}{l}\text { Betweenness } \\
\text { Centrality Rank }\end{array}$ & $\begin{array}{c}\text { Cumulative } \\
\text { Percent }\end{array}$ \\
\hline 46 & 2 & 6 & 0 & 119 & 100.0 \\
\hline 47 & 2 & 6 & 0 & 120 & 100.0 \\
\hline 49 & 128 & 6 & 0 & 121 & 100.0 \\
\hline 50 & 845 & 8 & 0 & 122 & 100.0 \\
\hline 52 & 108 & 6 & 0 & 123 & 100.0 \\
\hline 53 & 2 & 6 & 0 & 124 & 100.0 \\
\hline 54 & 172 & 10 & 0 & 125 & 100.0 \\
\hline 56 & 4,967 & 8 & 0 & 126 & 100.0 \\
\hline 57 & 200 & 4 & 0 & 127 & 100.0 \\
\hline 59 & 1 & 2 & 0 & 128 & 100.0 \\
\hline 60 & 15 & 6 & 0 & 129 & 100.0 \\
\hline 63 & 2 & 8 & 0 & 130 & 100.0 \\
\hline 66 & 399 & 10 & 0 & 131 & 100.0 \\
\hline 67 & 2,474 & 14 & 0 & 132 & 100.0 \\
\hline 70 & 2 & 10 & 0 & 133 & 100.0 \\
\hline 73 & 1 & 4 & 0 & 134 & 100.0 \\
\hline 75 & 1 & 8 & 0 & 135 & 100.0 \\
\hline 76 & 31 & 8 & 0 & 136 & 100.0 \\
\hline 77 & 58 & 14 & 0 & 137 & 100.0 \\
\hline 79 & 6 & 2 & 0 & 138 & 100.0 \\
\hline 82 & 648 & 6 & 0 & 139 & 100.0 \\
\hline 85 & 1 & 4 & 0 & 140 & 100.0 \\
\hline 87 & 145 & 12 & 0 & 141 & 100.0 \\
\hline 88 & 12 & 12 & 0 & 142 & 100.0 \\
\hline 89 & 2 & 4 & 0 & 143 & 100.0 \\
\hline 90 & 3 & 4 & 0 & 144 & 100.0 \\
\hline 92 & 1 & 2 & 0 & 145 & 100.0 \\
\hline 93 & 6 & 4 & 0 & 146 & 100.0 \\
\hline 94 & 1,046 & 10 & 0 & 147 & 100.0 \\
\hline 96 & 891 & 14 & 0 & 148 & 100.0 \\
\hline 97 & 7 & 4 & 0 & 149 & 100.0 \\
\hline 99 & 1 & 2 & 0 & 150 & 100.0 \\
\hline 100 & 2 & 4 & 0 & 151 & 100.0 \\
\hline 102 & 109 & 12 & 0 & 152 & 100.0 \\
\hline 103 & 37 & 10 & 0 & 153 & 100.0 \\
\hline 104 & 2,960 & 8 & 0 & 154 & 100.0 \\
\hline 106 & 697 & 4 & 0 & 155 & 100.0 \\
\hline 113 & 1,504 & 4 & 0 & 156 & 100.0 \\
\hline 115 & 7 & 6 & 0 & 157 & 100.0 \\
\hline 116 & 2,071 & 12 & 0 & 158 & 100.0 \\
\hline 117 & 342 & 18 & 0 & 159 & 100.0 \\
\hline
\end{tabular}




\begin{tabular}{|c|c|c|c|c|c|}
\hline $\begin{array}{c}\text { Priority Area } \\
\text { ID }\end{array}$ & $\begin{array}{l}\text { Area } \\
\left(\mathrm{km}^{2}\right)\end{array}$ & $\begin{array}{c}\text { Degree } \\
\text { Centrality }\end{array}$ & $\begin{array}{l}\text { Betweenness } \\
\text { Centrality }\end{array}$ & $\begin{array}{c}\text { Betweenness } \\
\text { Centrality Rank }\end{array}$ & $\begin{array}{l}\text { Cumulative } \\
\text { Percent }\end{array}$ \\
\hline 124 & 2 & 6 & 0 & 160 & 100.0 \\
\hline 126 & 555 & 6 & 0 & 161 & 100.0 \\
\hline 128 & 357 & 8 & 0 & 162 & 100.0 \\
\hline 130 & 352 & 10 & 0 & 163 & 100.0 \\
\hline 132 & 48 & 8 & 0 & 164 & 100.0 \\
\hline 136 & 481 & 4 & 0 & 165 & 100.0 \\
\hline 140 & 556 & 6 & 0 & 166 & 100.0 \\
\hline 145 & 125 & 4 & 0 & 167 & 100.0 \\
\hline 147 & 316 & 4 & 0 & 168 & 100.0 \\
\hline 149 & 7 & 10 & 0 & 169 & 100.0 \\
\hline 150 & 2,456 & 4 & 0 & 170 & 100.0 \\
\hline 151 & 2,121 & 10 & 0 & 171 & 100.0 \\
\hline 153 & 2 & 8 & 0 & 172 & 100.0 \\
\hline 154 & 2 & 10 & 0 & 173 & 100.0 \\
\hline 155 & 7 & 10 & 0 & 174 & 100.0 \\
\hline 156 & 2 & 6 & 0 & 175 & 100.0 \\
\hline 159 & 5 & 8 & 0 & 176 & 100.0 \\
\hline 163 & 1 & 8 & 0 & 177 & 100.0 \\
\hline 164 & 8 & 12 & 0 & 178 & 100.0 \\
\hline 165 & 21 & 6 & 0 & 179 & 100.0 \\
\hline 168 & 11 & 6 & 0 & 180 & 100.0 \\
\hline 172 & 145 & 6 & 0 & 181 & 100.0 \\
\hline 173 & 1,044 & 10 & 0 & 182 & 100.0 \\
\hline 179 & 4,437 & 4 & 0 & 183 & 100.0 \\
\hline 180 & 490 & 6 & 0 & 184 & 100.0 \\
\hline 183 & 105 & 10 & 0 & 185 & 100.0 \\
\hline 186 & 199 & 12 & 0 & 186 & 100.0 \\
\hline 187 & 6 & 4 & 0 & 187 & 100.0 \\
\hline 188 & 17 & 2 & 0 & 188 & 100.0 \\
\hline
\end{tabular}


Publishing support provided by the U.S. Geological Survey Science Publishing Network, Tacoma Publishing Service Center

For more information concerning the research in this report, contact the Director, Forest and Rangeland Ecosystem Science Center U.S. Geological Survey

777 NW 9th St., Suite 400

Corvallis, Oregon 97330

http://fresc.usgs.gov/ 
